\title{
COLEGIALIDADE, INTEGRIDADE E DELIBERAÇÃO: OS PRECEDENTES E O CONTRADITÓRIO NO NOVO CPC
}

\author{
COLLEGIALITY, INTEGRITY AND DELIBERATION: JUDICIAL PRECEDENTS AND
}

ADVERSARIAL PRINCIPLE IN THE NEW BRAZILIAN CIVIL PROCEDURE CODE

Rafael Dilly Patrus*

\begin{abstract}
RESUMO: Na conjuntura que se arma em torno do novo Código de Processo Civil, a questão relativa à forma como os tribunais decidem é elevada a uma posição de enorme relevância. O presente trabalho consiste em reflexão a respeito da ideia de deliberação para a produção e a prolação de decisões jurisdicionais colegiadas, em vista do sistema de precedentes vinculantes que se pretende implementar no ordenamento brasileiro. Conclui-se que, a despeito da necessidade de se conferir maior unidade aos acórdãos proferidos pelos tribunais, não se pode esvaziar a própria gênese do procedimento de tomada de decisões, o que abrange (ou deve abranger) não só o tipo de resultado e o contexto decisório, mas especialmente a intensidade das preferências daqueles que decidem. A divergência no curso da decisão não significa desatenção ao dever de integridade no decidir.
\end{abstract}

PALAVRAS-CHAVE: Sistema de precedentes vinculantes. Colegialidade jurisdicional. Integridade. Democracia deliberativa.
ABSTRACT: In light of the new Brazilian Civil Procedure Code, the question concerning the way courts decide is elevated to a position of enormous importance. This paper consists in a reflection on the idea of the role of deliberation in collegiate jurisdictional decisions, in view of the binding judicial precedents system to be implemented in Brazil. The conclusion is that, despite the need to bring greater unity to courts' decisions, the essence of the decisionmaking procedure cannot be emptied, since it includes (or should include) not only a kind of decision and the decision process, but especially the intensity of the preferences expressed by those making the decision. Divergences in the decision process does not mean lack of attention to the duty to decide with integrity.

KEYWORDS: System of binding precedents. Jurisdictional collegiality. Deliberative democracy.

SUMÁRIO: Introdução. 1 O Sistema de Precedentes no Novo Código de Processo Civil. 2 Os Precedentes e o Perigo da Fuga da Jurisdição. 3 Os Precedentes e o Contraditório. Conclusão. Referências.

\section{INTRODUÇÃO}

No II encontro dos jovens processualistas do Instituto Brasileiro de Direito Processual (IBDP), ocorrido em Salvador nos dias oito e nove de novembro de 2013, foi aprovado o enunciado segundo o qual "para a formação do precedente, somente podem ser usados argumentos submetidos ao contraditório". Consta da carta que o referido enunciado, gestado no seio do grupo de trabalho atinente aos precedentes judiciais, emanou do cruzamento interpretativo entre os artigos 10 e 521 do então projeto de novo Código de Processo Civil (hoje os artigos 10 e 927 da Lei 13.105, de 16 de março de 2015). Em outras palavras, a

\footnotetext{
* Mestre em Direito pela Universidade Federal de Minas Gerais (UFMG). Professor substituto de Direito Constitucional da Faculdade de Direito da Universidade Federal de Minas Gerais (UFMG), entre os anos de 2014 e 2015. Consultor Legislativo na Assembleia Legislativa do Estado de Minas Gerais. Vice-Presidente da Comissão de Estudos Constitucionais da Ordem dos Advogados de Minas Gerais (OAB-MG).
} 


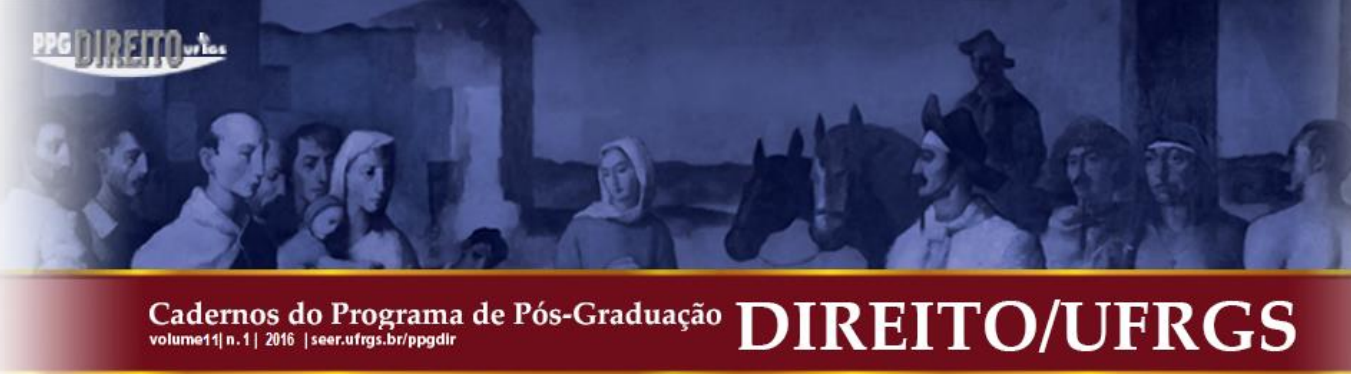

diretriz resulta da combinação entre a força vinculante dos precedentes e o contraditório material, duas máximas introduzidas pelo novo sistema processual. ${ }^{1}$

A despeito da clareza semântica do direcionamento, já à primeira vista uma série de indagações vem ao mundo. Como aferir, no caso concreto, a observância do contraditório na formação do precedente? Qual a medida adequada da submissão de um argumento ao contraditório? Um argumento não escrutinizado pode contaminar a força vinculante do precedente sobre o restante da argumentação? Se a parte reformula o argumento ou o refuta de maneira distinta, ao juiz é dado reconsiderar o precedente formado em atenção ao contraditório? Um argumento construído de forma insuficiente poderá compor o precedente simplesmente por ter sido debatido e avalizado pelas partes e pela autoridade jurisdicional? A que se refere um argumento propriamente dito? Uma questão pura de direito, ou uma questão de direito lida à luz da base fática da controvérsia? E em que consiste esse contraditório? Como ele se manifesta e se traduz no espaço público processual?

No presente estudo, não se tem a ingênua pretensão de responder a essas e às outras muitas perguntas que precisam ser feitas. A pretensão desta reflexão é, em verdade, muito mais tímida. O que se quer é colocar em debate o modelo deliberativo adotado pelos tribunais para a produção e a prolação de seus atos decisórios. Diante do quadro montado pelo novo Código e pelas discussões que dele têm decorrido, a maneira com que os colegiados jurisdicionais decidem consiste em questão de enorme relevância. O ponto nevrálgico situa-se sobretudo na ideia de colegialidade, a qual enceta uma verdadeira disputa em torno do prisma de deliberação adequado ao sistema de precedentes que se busca implementar.

Para tal consideração, procede-se inicialmente a uma descrição do regramento geral disposto no Código aprovado a respeito da formação e da aplicação dos precedentes judiciais. Em seguida, faz-se uma breve menção ao problema da fuga da jurisdição. Por fim, traz-se a lume a questão da colegialidade e, tendo como base a tese da democracia como processo decisório, analisam-se algumas ideias relativas à maneira como os tribunais decidem (e devem

\footnotetext{
${ }^{1}$ A adoção de um sistema de precedentes vinculantes consistiu em ponto dos mais nevrálgicos nos debates e embates em torno do novo Código de Processo Civil. Conforme anotam José Miguel Garcia Medina, Alexandre Freire e Alonso Reis Freire, a ideia encontrou "resistências ideológicas em certos setores da comunidade acadêmica, assim como no Poder Executivo, que, entre outras críticas, reputam inadequada a opção do projeto do novo Código de Processo pela adoção mais ostensiva do sistema de obrigatoriedade dos precedentes judiciais" (2013, p. 680). Neste estudo, parte-se da premissa interpretativa de que o Código aprovado no Congresso Nacional e encaminhado à sanção presidencial consagrou um verdadeiro sistema de precedentes obrigatórios, a despeito das expressões utilizadas (e não utilizadas) pela legislação.
} 


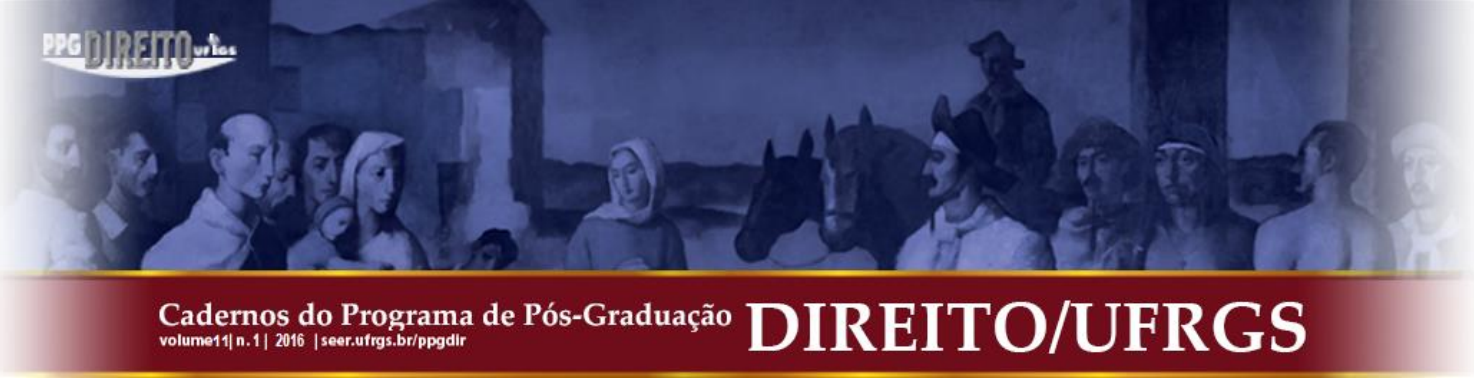

decidir). Em linhas gerais, o presente estudo se presta a externar a percepção de que, a despeito da necessidade de se conferir maior unidade aos acórdãos proferidos pelos tribunais, nomeadamente em vista da qualificação que o novo Código atribui aos precedentes que deles derivam, não se pode esvaziar a própria gênese do procedimento de tomada de decisões, o que abrange (ou deve abranger) não só o tipo de resultado e o contexto decisório, mas especialmente a intensidade das preferências daqueles que decidem. A divergência no curso da decisão não significa desatenção ao dever de integridade no decidir.

Não obstante esse escopo, o que se espera desta consideração é que ela sirva, acima de tudo, para a feitura de novas perguntas. O debate em torno do estabelecimento de um sistema processual mais justo e eficiente não se encerra com a aprovação de um novo Código. É sempre tempo de construir.

\section{O SISTEMA DE PRECEDENTES NO NOVO CÓDIGO DE PROCESSO CIVIL}

O caput do artigo 927 do novo Código de Processo Civil estipula que os órgãos jurisdicionais (juízes e tribunais) observarão os acórdãos do Supremo Tribunal Federal no exercício da fiscalização concentrada de constitucionalidade, os enunciados das súmulas vinculantes, as decisões em incidentes de assunção de competência e no julgamento de casos repetitivos, ${ }^{2}$ os enunciados de súmulas jurisprudenciais do Supremo em matéria constitucional e do Superior Tribunal de Justiça em matéria infraconstitucional, ${ }^{3}$ e as orientações dos plenários ou órgãos especiais aos quais se encontrem vinculados. ${ }^{4}$ Trata-se de diretrizes gerais para a utilização dos julgados proferidos pelos colegiados judiciais a título de precedentes.

\footnotetext{
${ }^{2} \mathrm{O}$ artigo 928 do novo Código esclarece que é considerado "julgamento de casos repetitivos a decisão proferida em: I - incidente de resolução de demandas repetitivas; II - recursos especial e extraordinário repetitivos".

${ }^{3}$ Apesar de o uso do termo "infraconstitucional" não ensejar, a princípio, maiores questionamentos, a menção feita pelo legislador é atécnica, sobretudo quando se leva em conta que o Código de Processo Civil consiste em diploma processual de caráter geral, aplicável direta ou subsidiariamente às justiças especializadas. A rigor, os precedentes emanados pelo Superior Tribunal de Justiça são vinculantes, à luz da Constituição da República, para a interpretação e a aplicação da legislação federal não especial, excluindo-se as matérias atinentes à legislação local e as cuja apreciação é de competência da Justiça do Trabalho, da Justiça Eleitoral ou da Justiça Militar Federal.

${ }^{4}$ Art. 927. Os juízes e os tribunais observarão: I - as decisões do Supremo Tribunal Federal em controle concentrado de constitucionalidade; II - os enunciados de súmula vinculante; III - os acórdãos em incidente de assunção de competência ou de resolução de demandas repetitivas e em julgamento de recursos extraordinário e especial repetitivos; IV - os enunciados das súmulas do Supremo Tribunal Federal em matéria constitucional e do Superior Tribunal de Justiça em matéria infraconstitucional; V - a orientação do plenário ou do órgão especial aos quais estiverem vinculados.
} 


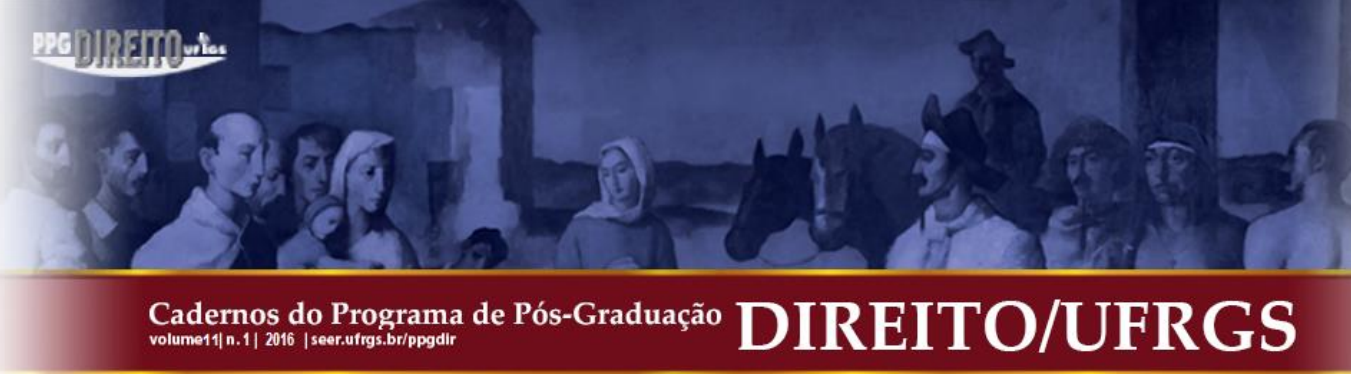

Para a realização sustentável dessa proposta, o caput do artigo 926, por sua vez, estipula que cumpre aos tribunais "uniformizar sua jurisprudência e mantê-la estável, íntegra e coerente". 5

$\mathrm{Na}$ redação do Código aprovado, não há referência expressa aos princípios que devem nortear a formação desses precedentes. Isso não significa, contudo, que a prolação das decisões a que faz alusão o artigo 927 não deva subserviência à autoridade dos princípios da legalidade, da segurança jurídica, da proteção da confiança e do contraditório, já que a obrigatoriedade dessas diretrizes decorre da própria ordem constitucional (DERZI, 2009, p. 377-498). Além disso, outras disposições, especificamente concernentes às exigências que devem ser observadas pelos juízes e tribunais quando da aplicação dos precedentes e/ou às hipóteses de modificação da jurisprudência dominante do Supremo Tribunal Federal e do Superior Tribunal de Justiça, servem como indicadores claros da meta de materialização policêntrica, comparticipativa e, por isso mesmo, democrática que orienta a organização do espaço público processual no novo diploma (NUNES, 2004, p. 73-85; 2008; NUNES; THEODORO JÚNIOR, 2009a, p. 177-206; 2009b, p. 107-141).

Um exemplo é o $§ 1^{\circ}$ do artigo 926, que preleciona que "os tribunais editarão enunciados de súmula correspondentes a sua jurisprudência dominante", mas atendo-se, por força do que estabelece o $\S 2^{\circ}$, “às circunstancias fáticas dos precedentes que motivaram sua criação". O encaminhamento dado pelo Código é claro quanto ao escopo de racionalizar o uso das súmulas jurisprudenciais, tão pauperizadas na prática forense nacional, ${ }^{6}$ de modo que a aplicabilidade do precedente exarado pelos tribunais hierarquicamente superiores implique um processo de adequação discursiva na concretização levada a efeito pelas instâncias inferiores. Essa obrigatoriedade, se tomada com o cuidado e a inteligência que a implementação de um novo sistema processual exige, pode ser lida como um instrumento de proteção sistêmica da segurança e da confiança, porquanto assegura que o respaldo e a identidade das orientações sumulares estejam deitados na história institucional da própria comunidade político-jurídica. ${ }^{7}$

O $\S 1^{\circ}$ do artigo 927 traz ainda a importante previsão de que o órgão jurisdicional deverá observar o disposto no artigo 10 e no artigo 489, $\S 1^{\circ}$, na aplicação dos precedentes referidos

\footnotetext{
${ }^{5}$ Art. 926. Os tribunais devem uniformizar sua jurisprudência e mantê-la estável, íntegra e coerente.

${ }^{6}$ Para uma crítica da utilização das súmulas no direito brasileiro, cf., por todos, Bustamante (2013, p. 65-106).

${ }^{7}$ Para um estudo da relação entre tempo e confiança na obra de Niklas Luhmann, cf. Derzi (2009, p. 316-338). 


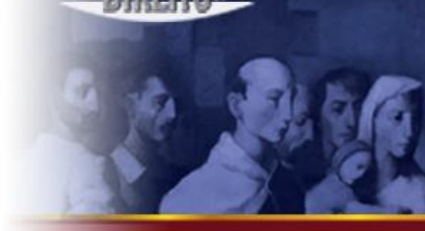

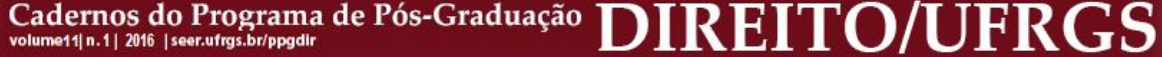

no caput. ${ }^{8}$ Tal dispositivo traz à tona a relevância da materialização do contraditório na atribuição de força vinculante aos argumentos de um precedente. De um lado, a vedação a que o órgão jurisdicional decida com base em fundamento a respeito do qual não se tenha oportunizado manifestação das partes impõe que o elemento de fundamentação componente do ato de aplicação de um precedente tenha sido submetido ao contraditório. De outro, a decisão concreta que não promover adequadamente a individualização, a adaptação e a reconstrução da norma extraída do precedente será considerada carente de motivação.

Outrossim, o Código dá grande importância à modificação da jurisprudência, prescrevendo, no $\S 2^{\circ}$ do artigo 927, que a variação de tese jurídica constante de enunciado de súmula ou decisão em julgamento de casos repetitivos "poderá ser precedida de audiências públicas e da participação de pessoas, órgãos ou entidades que possam contribuir para a rediscussão da tese". Em acréscimo, o $\S 3^{\circ}$ estabelece que, "na hipótese de alteração de jurisprudência dominante do Supremo Tribunal Federal e dos tribunais superiores ou daquela oriunda de julgamento de casos repetitivos, pode haver modulação dos efeitos da alteração no interesse social e no da segurança jurídica”.

Vê-se que, tanto na formação quanto na modificação da diretriz jurisprudencial sedimentada, a observância do contraditório material é impositiva, não apenas em razão do que estabelece o artigo 10, mas principalmente o artigo 926, caput, que consubstancia norma de caráter geral na conformação do sistema de precedentes. Em acréscimo, vale mencionar a exigência materializadora inscrita no $\S 4^{\circ}$ do artigo 927, segundo a qual a alteração de entendimento jurisprudencial sedimentado "observará a necessidade de fundamentação adequada e específica, considerando os princípios da segurança jurídica, da proteção da confiança e da isonomia".

\footnotetext{
${ }^{8}$ Art. 10. Em qualquer grau de jurisdição, o órgão jurisdicional não pode decidir com base em fundamento a respeito do qual não se tenha oportunizado manifestação das partes, ainda que se trate de matéria apreciável de ofício.

Art. 489. (...) $\S 1^{\circ}$ Não se considera fundamentada qualquer decisão judicial, seja ela interlocutória, sentença ou acórdão, que: I - se limitar à indicação, à reprodução ou à paráfrase de ato normativo, sem explicar sua relação com a causa ou a questão decidida; II - empregar conceitos jurídicos indeterminados, sem explicar o motivo concreto de sua incidência no caso; III - invocar motivos que se prestariam a justificar qualquer outra decisão; IV - não enfrentar todos os argumentos deduzidos no processo capazes de, em tese, infirmar a conclusão adotada pelo julgador; $\mathrm{V}$ - se limitar a invocar precedente ou enunciado de súmula, sem identificar seus fundamentos determinantes nem demonstrar que o caso sob julgamento se ajusta àqueles fundamentos; VI - deixar de seguir enunciado de súmula, jurisprudência ou precedente invocado pela parte, sem demonstrar a existência de distinção no caso em julgamento ou a superação do entendimento.
} 


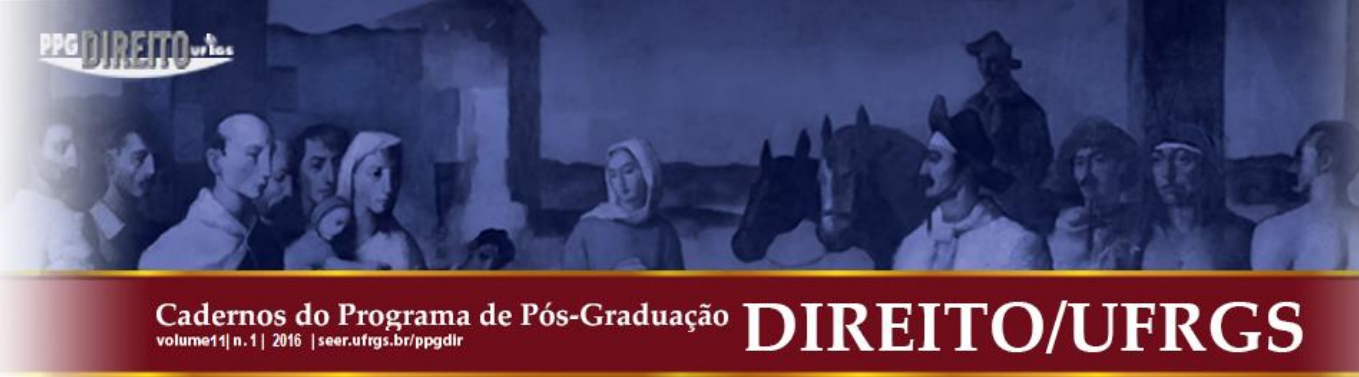

De modo geral, o Código se posiciona contrariamente à instabilidade da jurisprudência. Nessa seara, é posta em evidência a noção do colegiado judicial como fórum responsável pela salvaguarda da integridade e da unidade dos enunciados emanados no formato de precedentes. A implementação adequada dos argumentos pelos julgadores nos casos posteriores exigirá a preservação desse liame. Por isso mesmo, a preocupação atinente à forma como os tribunais decidem mostra-se fundamental.

\section{OS PRECEDENTES E O PERIGO DA FUGA DA JURISDIÇÃO}

O manuseio de um sistema de precedentes vinculantes pela lógica do princípio da praticidade é altamente nocivo, podendo levar "a uma administração da justiça informada exclusivamente por argumentos pragmáticos e voltada para uma padronização massificadora da atividade jurisdicional" (DERZI; BUSTAMANTE, 2013, p. 333-334). Isso porque, ao proceder a uma implementação maquinal e não reflexiva dos enunciados jurisprudenciais, ${ }^{9} \mathrm{o}$ julgador se afasta de seu dever de individualizar o direito, no sentido de adequá-lo às peculiaridades concretas e reconstrui-lo dialeticamente à luz da razão pública e da comunidade de princípios (RAWLS, 2005; DWORKIN, 1986; 1996).

Ao Poder Judiciário a ordem constitucional atribuiu a importante função de dirimir e pacificar as controvérsias sociais, lançando mão de uma estrutura distributiva de justiça que toma o conflito concreto como medida de equalização. Em outras palavras, a atuação jurisdicional, não obstante a importância das diretrizes e orientações uniformizadoras, implica a consideração da concretude em sua particularidade. Portanto, quando o juiz se nega a analisar o caso concreto, supondo suficiente a média aferida pelo legislador ou pelo administrador a partir de uma leitura rasa das hipóteses reais mais frequentes, há uma verdadeira recusa de prestação jurisdicional, ou, em outras palavras, uma negativa de cumprimento da função institucional outorgada à parcela da soberania estatal atrelada à aplicação do direito para a solução dos conflitos sociais (DERZI, 2012, p. 611-612; DERZI;

\footnotetext{
${ }^{9}$ No Brasil, contudo, as duas posturas mais comuns no uso dos julgados como fundamento para as decisões são: a repetição mecânica de ementas e súmulas, em desatenção ao contexto dos fundamentos determinantes, e o desprezo pelas decisões previamente proferidas, como se fosse possível demarcar o momento decisório a partir de um referencial-zero na densificação interpretativa do direito. Para uma crítica dessa tendência, cf. Bustamante (2013, p. 65-106).
}

Cadernos do Programa de Pós-Graduação em Direito PPGDir./UFRGS | Edição Digital | Porto Alegre | Volume XI | Número 1 | 2016 | P. 268-298 


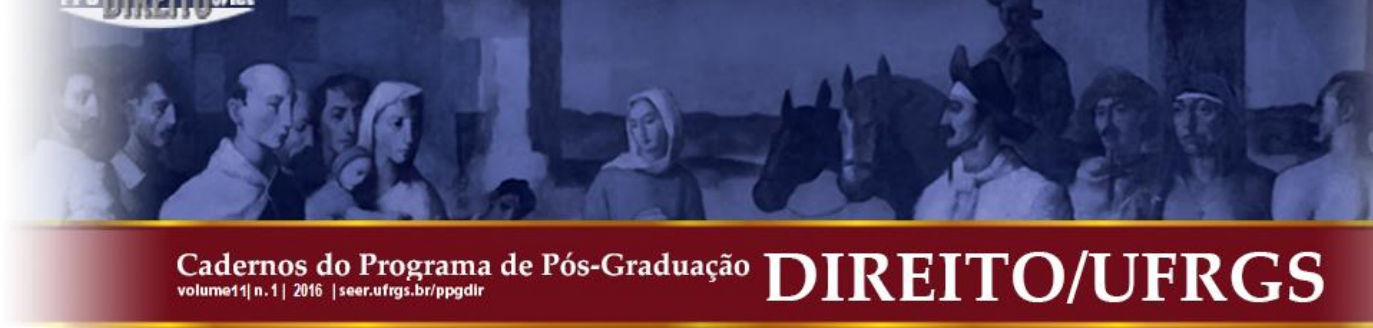

BUSTAMANTE, 2013, pp. 333-336). ${ }^{10}$ Essa perspectiva não importa na negação da normatividade da jurisprudência dos tribunais, conforme anota Misabel Derzi:

\begin{abstract}
Não se nega, evidentemente, que a norma judicial, extraída da jurisprudência dominante, crie expectativa normativa e imponha-se a terceiros que não integraram a lide ou casos em que ela se firmou. (...) Isso não significa, entretanto, que o Poder Judiciário fica dispensado do exame profundo de cada caso concreto que se lhe apresente, pois a súmula e a jurisprudência dominante somente podem ser aplicadas se e na medida em que o caso sub judice demonstre preencher e enquadrar-se nos pressupostos e casos sumulados (DERZI, 2012, p. 612).
\end{abstract}

Assim, a utilização do precedente no acertamento e no julgamento das contendas depende do comprometimento com uma "coerência diacrônica" entre o passado e o presente: a ideia de que a resposta para o problema de hoje deve ser extraída de uma construção que leve em conta os direcionamentos universais (e universalizantes) de ontem e ao mesmo tempo se projete, reflexiva e criticamente, como condicionamento universal (e universalizante) para as questões e os problemas de amanhã (MELISSARIS, 2006, pp. 129-141). ${ }^{11}$ A justificação das decisões está amarrada a uma exigência de universalizabilidade de cada solução concreta. A individualização do precedente a partir de um discurso de aplicação não supõe, destarte, um casuísmo divorciado da regência normativa geral, nomeadamente porque os comunicantes devem se empenhar na edificação de fundamentos decisórios que sirvam não só para o problema atual, mas atendam aos requisitos pregressos, na medida da história institucional do direito, e aos casos futuros que lhe sejam similares. Um discurso de adequação importa, nesse cenário, na aplicação das normas a cada situação concreta a partir de sua reinterpretação e de seu ajustamento às particularidades verificadas (DERZI; BUSTAMANTE, 2013, p. 335). A atividade hermenêutica do agente judicial depende dessa percepção. ${ }^{12}$

\footnotetext{
${ }^{10}$ Para a elucidação dessa questão, mostra-se indispensável a lição de Misabel Derzi: “Cabe ao Legislador (...) a justiça geral (por todos e para todos), sem corporativismos e privilégios. Mas ao Poder Judiciário cabe pacificar os conflitos, por meio da distribuição da justiça individual, caso a caso. Não pode o Poder Judiciário recusar-se a examinar o caso concreto, na suposição de que o administrador ou o legislador tenham tipificado razoavelmente pela média ou segundo os casos mais frequentes. Utilizar-se o Poder Judiciário de presunções, tipificações convertidas em súmulas (vinculantes ou não) para evitar uma série de demandas e, com isso, reduzir os casos em juízo, é fugir à função constitucional que lhe foi outorgada. Na praticidade, prevalece o quantitativo sobre a qualidade" (2012, p. 611).

${ }^{11}$ Thomas de Bustamante e Misabel Derzi pontuam que "o denominado princípio da 'justiça formal', argumenta MacCormick, exige uma espécie de coerência diacrônica entre os precedentes, na medida em que todos os falantes devem se 'comprometer em estabelecer os fundamentos para a decisão de hoje e de todos os casos futuros que lhe sejam semelhantes"” (2013, p. 335). A citação feita pelos autores é a MacCormick (1978, p. 76).

${ }^{12}$ Nesse sentido: “A aplicação das súmulas jurisprudenciais exige, portanto, uma consideração específica das circunstâncias de cada caso concreto, sob pena de uma aplicação irreflexiva e mal fundamentada dessa espécie de fonte do direito. Com efeito, abstrair-se do contexto determinado pela situação concreta de cada caso posto sob a esfera do Judiciário implica o abandono da própria perspectiva hermenêutica do intérprete em relação ao 


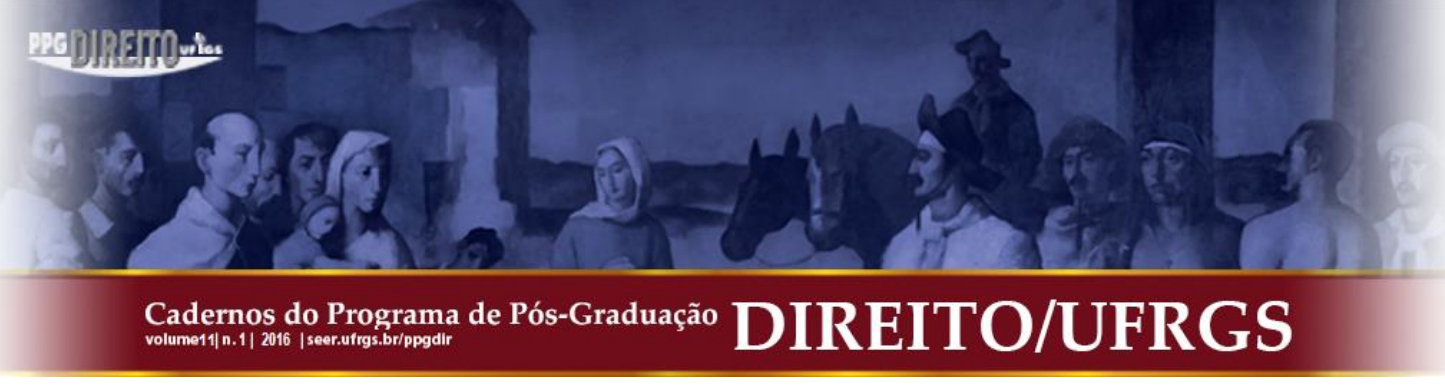

Na perspectiva do enunciado segundo o qual, para a formação dos precedentes, apenas podem ser utilizados argumentos submetidos ao contraditório, conforme aprovado no II encontro dos jovens processualistas do IBDP, em Salvador, a exigência da individualização concreta da diretriz normativa extraída do precedente é fortalecida. Se ao juiz é colocado o dever de isolar cada argumento que informa o precedente aplicável, de forma a verificar, no caso concreto, se o fundamento foi submetido ao contraditório quando de sua inclusão na orientação, a averiguação da compatibilidade entre as bases fáticas do enunciado e do caso concreto e a adaptação reconstrutiva do precedente ocorrem não apenas com maior fluidez, mas passam verdadeiramente a compor o cerne estrutural da atividade judicante. Em outras palavras, a interpretação conjunta dos comandos insertos nos artigos 10,489, $\S 1^{\circ}$ e 926 e seguintes do novo Código de Processo Civil apresenta-se como recurso de afirmação da prestação jurisdicional adequada, iluminando a designação do magistrado como responsável pela particularização universalizadora do direito na concretude, em vista da tensão processualizada entre o passado, o presente e o futuro.

$\mathrm{Na}$ apresentação de premissas para a legitimação discursiva do uso dos precedentes judiciais, Dierle Nunes afirma que o "processualismo constitucional democrático", base da sistemática projetada no novo CPC, objetiva sobretudo

\begin{abstract}
discutir a aplicação de uma igualdade efetiva e valorizada, de modo policêntrico e comparticipativo, uma renovada defesa de convergência entre o civil law e o common law, ao buscar uma aplicação legítima e eficiente (efetiva) do direito para todas as litigiosidades (sem se aplicar padrões decisórios que pauperizam a análise e a reconstrução interpretativa do direito), e defendendo o delineamento de uma teoria dos precedentes para o Brasil que suplante a utilização mecânica dos julgados isolados e súmulas em nosso país (NUNES, 2011, p. 66). ${ }^{13}$
\end{abstract}

Assentadas essas elocuções, cabe perquirir a medida do contraditório exigido na formação dos precedentes. Se cumpre ao julgador selecionar os argumentos passíveis de

seu objeto. O jurista já não é mais visto como alguém que reflete sobre o direito e que - por via do discurso e do emprego de argumentos sobre a sua interpretação correta - interfere no 'contexto de uso' dos enunciados jurídicos, participando dos jogos de linguagem em que o significado desses enunciados é construído pela via da interpretação" (DERZI; BUSTAMANTE, 2013, p. 336). Para essa perspectiva analítica, cf. Bustamante (2012), MacCormick (1978) e Raz (1994).

${ }^{13}$ Em referência ao mesmo trabalho, Thomas de Bustamante e Misabel Derzi escrevem que as condições pensadas por Dierle Nunes "coincidem com as nossas reivindicações mais importantes para uma teoria brasileira - que ainda está por ser estabelecida - do precedente judicial” (2103, p. 359). E avançam, concluindo, no que toca à sistemática constante do então projeto de novo Código, que "as novas regras de interpretação do precedente judicial e de motivação das decisões podem contribuir, em importante medida, para a racionalização do processo decisório do poder judiciário. Isso, no entanto, se elas forem efetivamente respeitadas e interpretadas de forma correta, como propusemos nesse trabalho, pois caso contrário os precedentes serão apenas mais uma válvula de escape para o arbítrio judicial"' (2013, p. 362). 


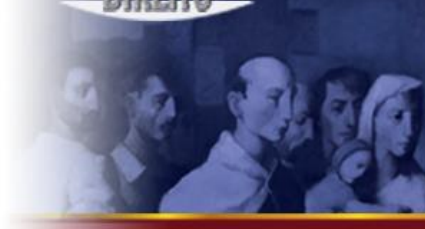

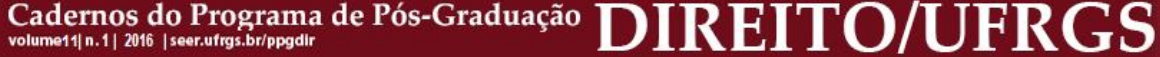

utilização a partir da fiscalização de sua submissão ao contraditório, é preciso mensurá-lo, defini-lo, delimitá-lo. Acima de tudo, a adequação do discurso de fundamentação, na construção do precedente, afeta essencialmente os discursos subsequentes de aplicação. Ou seja: o contraditório na gestação do enunciado vinculante é decisivo para a boa aplicação, nos casos presentes, das orientações precedentes. O modelo não pode cair no vício da (re)produção pela praticidade. Mais uma vez, essas razões confluem para elevar a forma de decisão dos tribunais à centralidade da discussão.

\section{OS PRECEDENTES E O CONTRADITÓRIO}

\subsection{O tormento da instabilidade jurisprudencial: o direito como integridade}

O tema da instabilidade jurisprudencial e da busca por soluções tem sido objeto de análise por parte de importantes doutrinadores já há algum tempo (ARRUDA ALVIM WAMBIER, 2001; DANTAS, 2013, pp. 125-143; MANCUSO, 2001). O artigo 926 do novo Código coloca essa preocupação em destaque ao estabelecer que "os tribunais devem uniformizar sua jurisprudência e mantê-la estável, íntegra e coerente”. É fácil perceber que o alvo de ataque consiste em um problema tormentoso para um sistema de precedentes judiciais vinculantes: a existência de parâmetros decisórios conflitantes, o que acaba por dificultar ou mesmo impedir a padronização de resultados para casos de base fática idêntica ou semelhante.

É inequívoco que, em grande medida, a instabilidade e a incoerência jurisprudenciais denotam um descuido dos tribunais quanto à exigência de decidir com integridade. Essa obrigatoriedade, de caráter hermenêutico e histórico-institucional, é revelada de maneira percuciente pelas considerações de Ronald Dworkin acerca do caráter interpretativo do direito, do dever judicial de decidir conforme a comunidade de princípios e da tese da única melhor resposta correta. ${ }^{14}$ A concepção do direito como uma projeção dialética de sua própria história, discursivamente compreendida e atualizada, impõe ao intérprete-julgador que assuma

\footnotetext{
${ }^{14}$ A tese da única melhor resposta correta, apresentada primeiramente em publicação da década de 1970 (DWORKIN, 1978), é retomada com maior profundidade na década de 1980 (DWORKIN, 1985; 1986). Cumpre esclarecer que, "fundamentalmente, a tese da única resposta correta não trata de afirmar que, semanticamente, qualquer juiz chegaria a uma mesma resposta, nem mesmo há uma exigência para se chegar, ainda que aproximadamente, a uma solução ideal. A tese da única resposta correta é, sobretudo, uma questão de postura ou atitude, definidas como interpretativas e autorreflexivas, críticas, construtivas e fraternas, em face do Direito como integridade, dos direitos individuais compreendidos como trunfos na discussão política e do exercício da jurisdição por aquele exigida; uma questão que, para Dworkin, não é metafísica, mas moral e jurídica" (CATTONI DE OLIVEIRA, 2012, p. 165-166).
} 


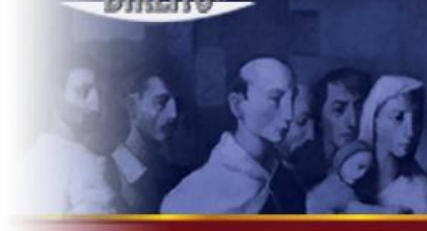

\section{Cadernos do Programa de Pós-Graduação
volume11|n.1| 2016 | seer.utrgs.br/ppgdir}

um posicionamento interpretativo, reflexivo e crítico-construtivo em face da institucionalidade positiva (DWORKIN, 1985; 1986; CATTONI DE OLIVEIRA, 2012, pp. 165-197). Nesses termos, tal concepção "rejeita tanto que as proposições jurídicas sejam notícias de fatos passados, como na perspectiva convencionalista, quanto que traduzam programas instrumentais focados nas consequências futuras, como quer o pragmatismo jurídico", insistindo, por sua vez, que "tais proposições consistem em julgamentos interpretativos e que, portanto, combinam elementos retrospectivos e prospectivos; interpretam a prática jurídica contemporânea como uma narrativa política em aberto". Para Dworkin, a teoria do direito como integridade "recusa como improfícua a velha questão sobre se os juízes enunciam ou inventam o direito", concebendo a fundamentação jurídica a partir da perspectiva de que "eles realizam ambas as atividades e nenhuma delas" (DWORKIN, 1986, p. 225 , tradução livre). ${ }^{15}$

Em linhas gerais, o princípio da integridade, em sua conformação adjudicativa, ${ }^{16}$ aponta que aos juízes cumpre

identificar direitos e deveres jurídicos, na maior medida possível, assumindo a premissa de que eles foram todos criados por um único autor - a comunidade personificada - na expressão de uma concepção coerente de justiça e justeza. (...). De acordo com a tese do direito como integridade, proposições jurídicas são verdadeiras na medida em que se ajustam aos ou decorrem dos princípios de justiça, justeza e devido processo que fornecem a melhor interpretação construtiva da prática jurídica da comunidade (DWORKIN, 1986, p. 225, tradução livre). ${ }^{17}$

Os compromissos institucionais que se originam dessa ideia elevam a história da comunidade político-jurídica a um patamar bastante específico de relevância hermenêutica. Não se trata de uma imposição de resgate de todos os estágios de desenvolvimento social do direito, mas da necessidade de assimilar o conteúdo histórico dos princípios compreendidos

\footnotetext{
${ }^{15} \mathrm{Na}$ redação original, os excertos foram retirados do seguinte trecho: "Law as integrity denies that statements of law are either the backward-looking factual reports of conventionalism or the forward-looking instrumental programs of legal pragmatism. Is insists that legal claims are interpretive judgments and therefore combine backward- and forward-looking elements; they interpret contemporary legal practice seen as an unfolding political narrative. So law as integrity rejects as unhelpful the ancient question whether judges find or invent law; we understand legal reasoning, it suggests, only by seeing the sense in which they do both and neither".

${ }^{16}$ A despeito da relevância da concepção do direito como integridade para a atividade jurisdicional, o princípio em si não se restringe ao âmbito judicante, impondo deveres hermenêuticos e histórico-institucionais também para o legislador e o administrador. Nessa linha de ideias, cf. Dworkin (1986, p. 176-224).

${ }^{17}$ No original: "The adjudicative principle of integrity instructs judges to identify legal rights and duties, so far as possible, on the assumption that they were all created by a single author - the community personified expressing a coherent conception of justice and fairness. (...). According to law as integrity, propositions of law are true if they figure in of follow from the principles of justice, fairness, and procedural due process that provide the best constructive interpretation of the community's legal practice".
} 


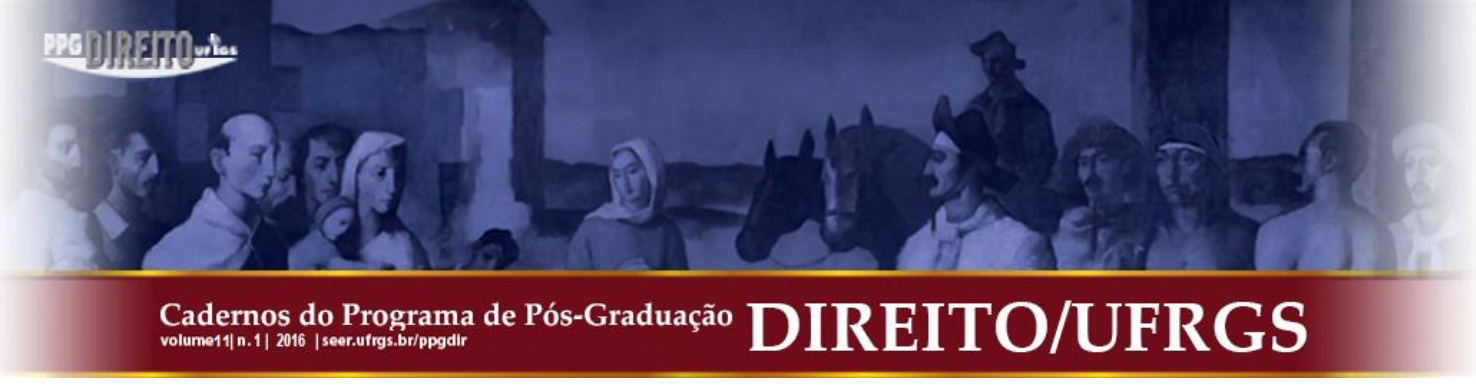

comunicativamente como justificadores dos direitos e deveres praticados no presente. $\mathrm{O}$ preceito da integridade situa o direito como um conjunto complexo de realizações "que emanam de decisões coletivas do passado e, por tal razão, autorizam ou exigem o uso da força”, mas compreende tais decisões não só a partir de seu conteúdo estrito e explícito, abarcando igualmente "o esquema de princípios necessário para justificá-las” (DWORKIN, 1986, p. 227, tradução livre). ${ }^{18}$ Há, portanto, um dever de reflexão crítica sobre o passado, em prol da adoção de uma postura interpretativa capaz de reproduzir institucionalmente a reconstrução do direito e de pensá-la de forma justa e coerente. Isso porque "não há como compreender sem se comprometer criticamente com uma prática jurídica que diz respeito a todos os que vivem sob o império do Direito" (CATTONI DE OLIVEIRA, 2012, p. 169). Daí a conclusão de que o direito

deve ser lido como parte de um empreendimento coletivo e compartilhado por toda a sociedade. Os direitos, assim, seriam frutos da história e da moralidade, no sentido de que observam uma construção histórico-institucional, a partir do compartilhamento de uma mesma sociedade de um mesmo conjunto de princípios e o reconhecimento de iguais direitos e liberdades subjetivas a todos os seus membros (comunidade de princípios) (FERNANDES, 2014, p. 195). ${ }^{19}$

Para a edificação de sua contribuição teórica, Dworkin lança mão de duas metáforas. A primeira é a metáfora do romance em cadeia. Cuida-se de um empreendimento confractual no qual um grupo de romancistas escreve em conjunto uma história em série, capítulo por capítulo. Cada autor é responsável por uma etapa do enredo. De um lado, a sua inserção pressupõe que as cenas e personagens já escritas sejam consideradas; lado outro, não há que se falar propriamente em um novo estágio narrativo sem o comprometimento com um avanço criativo. Há, portanto, uma responsabilidade pela continuidade, de modo que os escritores “aspirem conjuntamente à criação, tanto quanto puderem, de um romance único que seja o

\footnotetext{
${ }^{18}$ No original: "It [integrity] that the law - the rights and duties that flow from the past collective decisions and for that reason license or require coercion - contains not only the narrow explicit content of these decisions but also, more broadly, the scheme of principles necessary to justify them".

${ }^{19} \mathrm{O}$ autor dissocia a proposta de Dworkin de um suposto caráter não interpretacionista, no sentido atribuído por Ely (1980), na tentativa de escapar de "reduções drásticas a que uma diferenciação dicotômica presa ao debate clássico (...) estaria atrelada. Bem verdade é que o projeto dworkiniano é bem mais rico e amplo que o debate anterior, principalmente porque se assenta em uma compreensão do direito afeita às conquistas do giro linguístico e intimamente preocupada com a questão da busca por uma justificação da legitimidade do direito e das decisões jurídicas" (FERNANDES, 2014, p. 195).
} 
melhor possível" (DWORKIN, 1986, p. 229, tradução livre) ${ }^{20}$ Disso resulta a ideia de que, no tratamento das proposições jurídicas, os intérpretes (em especial, os magistrados) assumam a postura de um artista que ao mesmo tempo descreve e cria, no sentido de ler e simultaneamente elaborar a melhor história possível (a história posta, lida à sua melhor luz) (DWORKIN, 1986, p. 228-238). ${ }^{21}$ Com essa figura de linguagem, Dworkin defende a alocação da atividade adjudicativa em um lugar de atenção à história institucional do direito. Seu objetivo é corroborar que decidir com integridade implica engajar-se em um cometimento essencialmente coletivo, de forma que cada nova decisão resulte não só de uma leitura inventiva do direito adaptado e atualizado ao caso concreto enfrentado, mas importe em uma consideração crítica dos rumos pregressos, em especial os precedentes judiciais.

Em acréscimo a tal ideia, o autor constrói a metáfora do juiz Hércules, que representa um julgador-intérprete sobre-humano, com inserção em determinada comunidade de princípios, munido confractualmente ${ }^{22}$ da aptidão, da disposição e da envergadura necessárias à recuperação hermenêutica e à densificação principiológica da história institucional do direito. Esse exercício interpretativo serve, no horizonte de Hércules, para o isolamento, frente a determinado problema concreto, da única solução correta. A aproximação dos magistrados reais à figura mitológica ocorre de maneira limitada, mas a sua explicitação põe em evidência o dever de buscá-la e realizá-la tanto quanto possível. Na perspectiva do direito como integridade, aos juízes cumpre decidir corretamente; trata-se de um dever institucional, oriundo especialmente do comprometimento hermenêutico que o julgador deve assumir com a comunidade de princípios à qual ele serve.

Essas formulações ajudam a compreender o tamanho da carência institucional gerada por uma jurisprudência inconstante e contraditória. A inobservância da exigência de integridade é um mal imenso para quaisquer sistemas jurídicos, sobretudo aqueles nos quais vigora uma aparelhagem de precedentes judiciais vinculantes. Por isso mesmo, afigura-se não

\footnotetext{
${ }^{20} \mathrm{O}$ excerto original foi retirado da seguinte passagem: "In our example (...), the novelists are expected to take their responsibilities of continuity more seriously; they aim jointly to create, so far as they can, a single unified novel that is the best it can be".

${ }^{21}$ Para exemplificar a proposta por trás da metáfora, Dworkin faz menção ao personagem Scrooge da obra $A$ Christmas Carol, de Charles Dickens (1986, p. 232-238). Para uma revisão de como o direito se assemelha à literatura, cf. Cattoni de Oliveira (2012, p. 165-197).

${ }^{22}$ Dworkin anota que "nenhum juiz seria capaz de compor algo próximo a uma interpretação completa e imediata de todo o direito de sua comunidade. Por essa razão, imaginaremos um julgador hercúleo, com talentos sobre-humanos e tempo infinito" (1986, p. 245, tradução livre). No original: "No actual judge could compose anything approaching a full interpretation of all his community's law at once. That is why we are imagining a Herculean judge of superhuman talents and endless time".
} 


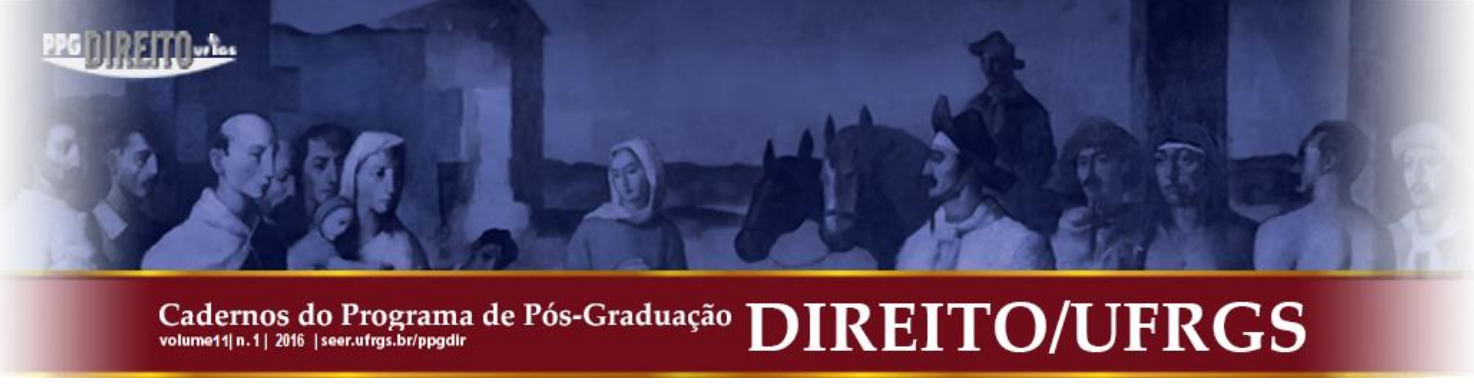

só compreensível como salutar a inquietude do novo Código com a estabilidade, a higidez e a coerência dos entendimentos consolidados dos tribunais. E mais: essa preocupação - que não é nova, apesar de agora passar a constar do texto legal - enceta, evidentemente, uma revisão na forma como as decisões colegiadas são tomadas. Nunca é demais repetir que a maneira como os tribunais decidem constitui um problema central. $\mathrm{O}$ que não se pode aceitar, por outro lado, é que a constatação dessa centralidade sirva de apoio para suposições metodológicas avessas à permeabilidade da jurisdição como espaço público de lutas por direitos. Não será em prol da estabilidade jurisprudencial que o desacordo deliberativo será tomado como um problema de falta de integridade.

\subsection{A fórmula deliberativa da colegialidade}

Qual o significado, então, do contraditório exigido para que determinado fundamento integrante do precedente adquira força normativa? A indagação não pode ser encarada de forma simplória. Tampouco se pode enfrentá-la à luz do contraditório material que se pretende efetivar no âmbito do processo civil individual (NUNES; THEODORO JÚNIOR, 2009b, pp. 107-141). Os jurisdicionados afetados pelo discurso de aplicação construído a partir do precedente não são aqueles que diretamente contribuíram para a construção do respectivo discurso de fundamentação. ${ }^{23}$

A percepção da distinção entre essas duas dimensões discursivas é fundamental para a compreensão da reconstrução do direito no marco da ordem democrática, sobretudo quando se tem em mente, com Klaus Günther, que o questionamento relativo à validade de determinada norma jurídica é distinto do alusivo à sua aplicação adequada (GÜNTHER, 1993). ${ }^{24} \mathrm{~A}$

\footnotetext{
${ }^{23}$ Assume-se, no presente trabalho, que o discurso de aplicação engendrado pelos tribunais quando da produção de uma decisão apta a adquirir a força de um precedente se metamorfoseia, subsequentemente, em um discurso de fundamentação, na medida em que serve de parâmetro para as etapas de aplicação que ocorrerão perante as instâncias ordinárias. Embora idealmente afeito às bases fáticas dos casos a partir dos quais o precedente foi gestado, esse parâmetro se manifesta como uma orientação dotada de algum grau de abstração e generalidade, motivo pelo qual exige, na individualização do direito, um novo discurso de densificação capaz de adequá-lo à concretude analisada. Não se pretende dizer, com isso, que o processo decisório do qual resulta o precedente judicial é equivalente à manifestação do discurso de fundamentação legislativo, mas que, na esteira do que preleciona Klaus Günther, há uma diferença essencial entre a pergunta sobre a fundamentação apropriada do precedente e a pergunta sobre a adequação da sua aplicação.

${ }^{24}$ Sobre essa separação, Flávio Pedron pontua que "para toda norma que for aceita como válida a partir de um princípio de universalização, haverá situações nas quais essa mesma norma, aparentemente, poderá se 'chocar' com outra norma igualmente válida, de modo que será possível seguir uma sem descumprir outra" (2008, p. 189).
} 


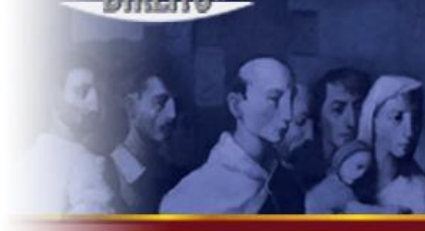

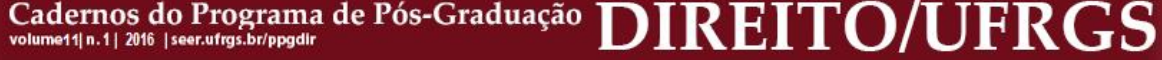

fundamentação aloca-se discursivamente no processo democrático de elaboração da norma jurídica, ao passo que a aplicação consiste em etapa subsequente, manifestando-se nos processos democráticos de adaptação do enunciado normativo às situações concretas. São grandezas que não se confundem, e a principal distinção está no uso das formas de comunicação e dos possíveis recursos argumentativos (HABERMAS, 1992; 1996).

No primeiro, tratar-se-ia de perquirir sobre a validade das normas que seriam, posteriormente, aplicáveis prima facie, utilizando-se, para tanto, de um teste de universalização - a partir do princípio do discurso; no outro, pretender-se-ia considerar aquelas normas válidas e, então, diante de um caso concreto especifico, buscar encontrar a norma que seja adequada (PEDRON, 2008, p. 188).

Não se ignora que a produção de uma norma leva inevitavelmente em conta uma dimensão de aplicação, em vista dos objetivos, efeitos e impactos que a sua colocação subentende e enseja. A distinção entre os discursos de fundamentação e de aplicação não assume a existência de um hiato hermenêutico entre o processo de concepção geral da expectativa de conduta e a sua implementação para a solução de um problema concreto. ${ }^{25} \mathrm{O}$ que se pressupõe é que há pretensões comunicativas completamente diferentes quando, de um lado, afirma-se que a norma é justificada adequada e imparcialmente e quando, de outro, dizse que a norma é aplicada adequada e imparcialmente (GÜNTHER, 1993, p. 87-88; PEDRON, 2008, p. 189). A assimilação dessa diferenciação possibilita repensar a perspectiva contrafactual de uma suposta colisão entre normas no discurso de aplicação. Esclarece-se que o conflito, na verdade, é falso, já que "quando se descobre a norma adequada, percebe-se que as demais permanecem igualmente válidas, apenas que nunca foram cabíveis para aquele caso" (BAHIA, 2003, p. 255, grifo no original).

Outrossim, não se discute que o discurso de formação de um precedente judicial é distinto do discurso de fundamentação concernente à elaboração legislativa do preceito normativo. ${ }^{26}$ As formas comunicativas e os recursos de argumentação à disposição do

\footnotetext{
${ }^{25}$ Por isso mesmo, a crítica feita por Lenio Streck e Santiago Sito é descabida, porquanto assume, em uma postura hermenêutica radical, que a unidade entre compreensão e interpretação inutiliza a separação discursiva entre fundamentação e aplicação. Sobre esse posicionamento, cf. Streck e Sito (2012, p. 456-468).

${ }^{26}$ Sobre o tema, Flávio Pedron salienta que "por meio dos discursos de justificação, o legislador político avalia um espectro ilimitado de razões de normativas e pragmáticas, traduzindo-as à luz do código do Direito. O aplicador jurídico, por outro lado, encontra uma constelação de normas bem mais limitadas - ele apenas pode lançar mão das escolhas já feitas pelo legislador. Além disso, todas as escolhas do legislador, uma vez traduzidas conforme o código do Direito, agora funcionam sob a lógica jurídica; por isso mesmo, a tarefa deixada a cargo do aplicador não é mais de justificar tais razões, mas de encontrar, dentre as que o legislador considerou como prima facie válidas, a adequada para fornecer uma fundamentação acerca da correção da ação singular trazida pelo caso sub judice" (2008, p. 198).
} 


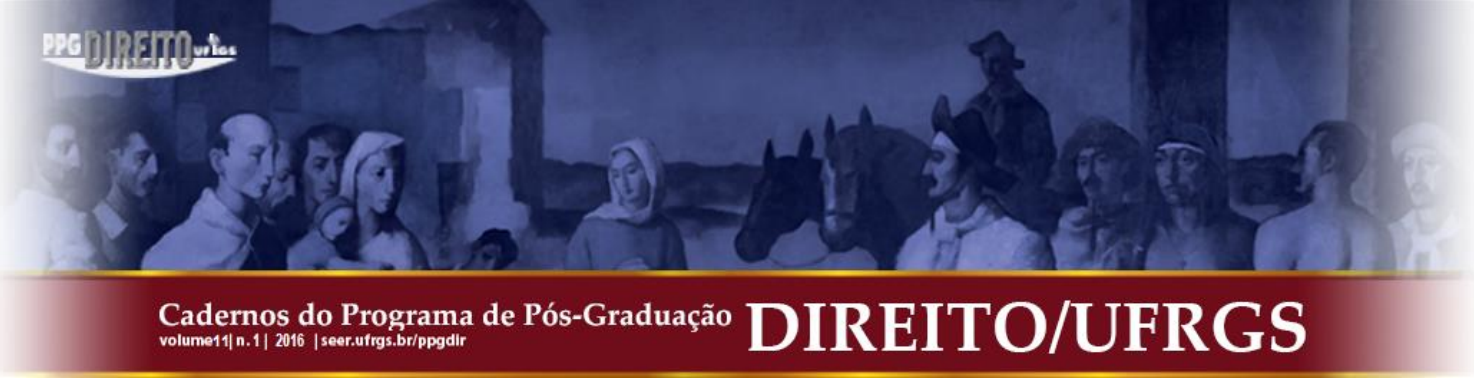

intérprete judicial não são (e nem podem ser) os mesmos, sob pena de mimetização e consequente esvaziamento da principal peculiaridade da via judicial para a gama de lutas por reconhecimento: o vocabulário da imparcialidade, da transparência argumentativa e do contraditório. ${ }^{27}$ Por conseguinte, uma medida importante do contraditório no desenrolar do discurso que culmina na formação de um precedente trata-se da colegialidade. Sem cair na ingenuidade de romantizar o potencial deliberativo das cortes, não há dúvidas de que o diálogo, consciente ou não, entre os julgadores inseridos no processo decisório consiste em aspecto indisponível da dialética público-processual de formação de um precedente. É na transparência comunicativa do processo decisório ocorrido perante os tribunais que se manifestam os elementos indicadores da atenção à exigência dworkiniana da integridade. A projeção de um julgador em direção à figura do juiz Hércules, com inserção no predicado do romance em cadeia, depende de um compromisso com a apresentação clara e honesta das razões jurídicas que o motivaram a decidir. Quando se fala em um grupo de magistrados, encarregados substancialmente de exarar, no discurso de aplicação circunscrito aos procedimentos mencionados pelo novo $\mathrm{CPC}$, um discurso de fundamentação para os casos futuros de base fática idêntica ou similar, o comprometimento com a clareza e a honestidade perpassa a adequação dos canais de comunicação que se estabelecem entre eles. A colegialidade está no cerne dessa linha de adequação. ${ }^{28}$ Mas, afinal, qual o significado dessa ideia para a relação discursiva entre os pares julgadores na formação de um precedente?

A colegialidade traduz, primeiramente, uma virtude de postura. Diz respeito à atitude assumida por um intérprete com relação aos seus colegas em um fórum deliberativo. Por meio

\footnotetext{
${ }^{27}$ Sobre a peculiaridade da via judicial para a veiculação das lutas que emergem do seio social, sobretudo no que se refere ao sentido do contraditório material, cf. Nunes (2006; 2008), Nunes e Theodoro Júnior (2009a, pp. 177206; 2009b, p. 107-141) e Bahia (2004, pp. 301-357; 2012, p. 15-37).

${ }^{28}$ Conrado Hübner Mendes menciona quatro virtudes que devem ser consideradas pelos juízes para o alcance do potencial deliberativo das cortes: a colegialidade, a empatia, a modéstia cognitiva e a ambição cognitiva. Nesse sentido: "A articulação colegiada é um método complexo de deliberação. Está orientado para o consenso, mas não depende dele. Lida com a tensão entre as promessas epistêmicas e comunitaristas, bem como com as razões de segunda ordem para a obtenção da unanimidade. Julgadores têm o encargo de encaminhar uma solução autoritária para o caso, de converter posições individuais em um pronunciamento institucional, sem suprimir os desacordos. Para desincumbir-se da sua responsabilidade deliberativamente, os juízes devem atentar para quatro virtudes: a colegialidade, a empatia, a modéstia cognitiva e a ambição cognitiva" (HÜBNER MENDES, 2014, p. 128, tradução livre). No original: "Collegial engagement is a complex mode of deliberation. It is oriented to consensus but does not depend on it. It deals with the tension between the epistemic and communitarian promises, and also with second-order reasons for reaching unanimity. Decision-makers have the burden of reaching an authoritative solution of the case, of converting individual positions into an institutional one, without suppressing disagreement. In order to discharge their responsibility in the deliberative way, judges should take four virtues into account: collegiality, empathy, cognitive modesty, and cognitive ambition".
} 


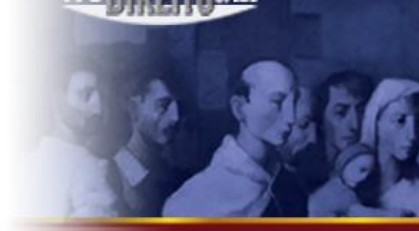

dela se constrói um projeto de colaboração, baseado em uma cultura de deliberação em prol da unidade colegiada (HÜBNER MENDES, 2014, p. 128-134). A colegialidade como impressão compartilhada impõe a busca pelo consenso, por meio de um desprendimento individual, de forma a sustentar uma performance institucional, despersonalizada e cooperativa.

A colegialidade como uma virtude deliberativa possui um significado preciso. Ela permanece, com efeito, vinculada a um projeto colaborativo, mas um que se mostre conectado com a cultura institucional interna vocacionada para a deliberação e em busca da unidade. Ela possibilita as condições para uma "controvérsia confortável" e desenvolve uma "intimidade além do afeto", nas expressões eloquentes utilizadas pelos juízes estadunidenses (HÜBNER MENDES, 2014, p. 129, tradução livre). ${ }^{29}$

Para Conrado Hübner Mendes, a colegialidade como princípio norteador da dinâmica deliberativa de um órgão jurisdicional implica uma série de outras virtudes, tais como o respeito pelas opiniões dos pares, a disposição à composição colaborativa e a humildade interpretativa. ${ }^{30}$ Nesse cenário, o empreendimento colegial importa em uma transmutação comunicativa da performance individual em prol da unidade coletiva, no sentido de uma articulação institucional coesa. Por essa razão, há carência de colegialidade na hipótese de "um juiz que, a despeito de ter estudado cuidadosamente o caso e elaborado razões bem pensadas para decidir, não se sente aberto a interagir e se comunicar com os seus colegas" (HÜBNER MENDES, 2014, p. 130, tradução livre). ${ }^{31}$

Diante disso, a solução do vício importaria na assunção de uma atitude comunicativa menos engessada. Porém, há, segundo o autor, hipóteses mais complexas, razão pela qual a colegialidade não se pode reduzir a um mero compromisso de cooperação, devendo pressupor

\footnotetext{
${ }^{29}$ No original: "Collegiality as a virtue of deliberation has a more precise sense. It remains, indeed, attached to a collaborative project, but one that is concerned with the internal institutional culture that favors deliberation and the search of unity. It generates the conditions for 'confortable controversy' and develops an 'intimacy beyond affection', in the eloquent expressions of American judges".

${ }^{30}$ Para a construção de tal percepção, Conrado Hübner Mendes faz referência aos escritos de Harry Edwards, segundo quem a colegialidade exige que "discutamos as visões alheias com seriedade e respeito, escutando com as mentes abertas", de modo que os julgadores estejam preparados para "ouvir, persuadir e ser persuadido, tudo isso em uma atmosfera de civilidade e respeito, possibilitando-se a criação "de condições para um acordo principiológico" (2014, p. 129, tradução livre) O trecho no original é o seguinte: "Edwards offers a more useful understanding. For him, rather than consensus, collegiality implies 'that we discuss each other's views seriously and respectfully, and that we listen with open minds'. In a more elaborated version, he claims that collegial judges are prepared to 'listen, persuade, and be persuaded, all in an atmosphere of civility and respect', and that such process 'helps to create the conditions for principled agreement'”. As citações feitas são a Edwards (1998, p. $1.361 ; 2003$, p. 1.645).

${ }^{31}$ No original: "Collegiality, therefore, is clearly at odds with a judge that, despite carefully studying the case and elaborating well-reflected reasons to decide, does not feel any responsibility to interact and communicate with his colleagues".
} 
uma disposição material para a ação supraindividual, sobretudo quando o acordo espontâneo não for possível (HÜBNER MENDES, 2014, p. 131-132). Em tal situação, os participantes do processo deliberativo-decisório devem se escorar em um compromisso principiológico, embora de ordem pragmática: o de que, em prol da não-divergência, ao intérprete inicialmente dissidente cabe "abrir mão de sua escolha primeira e filiar-se ao grupo. Eventualmente, aos juízes cumpre sujeitar-se em nome do poder simbólico e político de uma decisão unânime, em oposição à suscetibilidade de posicionamentos divididos" (HÜBNER MENDES, 2014, p. 130, tradução livre). ${ }^{32}$ Assim, para Hübner Mendes, o dissenso é por vezes encarado como o fracasso da unidade e da integridade grupais, uma anomalia admissível somente em último caso. Os juízes de um colegiado não devem, portanto, se escusar de promover ajustes até mesmo acerca das mais relevantes e delicadas questões morais e políticas, em vista da constatação do poder de uma decisão unânime - uma opinião institucional, do tribunal, e não uma soma das opiniões individuais dos julgadores. ${ }^{33}$

Não obstante a clareza dessa argumentação, o formato descrito mostra-se um tanto quanto questionável. À luz do maquinário de precedentes inscrito no novo $\mathrm{CPC}$, a questão toma uma proporção especial. Isso porque, frente à tarefa de alimentar e preservar a estabilidade da sua jurisprudência, não poderão os tribunais encarar o seu dever institucional de decidir com integridade como um convite a assumir compromissos pragmáticos em prol de posicionamentos falsamente unânimes ou majoritários.

Em reflexão sobre a obra de Hübner Mendes, Thomas de Bustamante assevera que a justificação de um colegiado judicial organizado e orientado pela lógica deliberativa do pragmatismo (ainda que norteado principiologicamente) não é capaz de responder às objeções feitas por vários autores ao próprio espaço de poder das cortes, nomeadamente no que se refere à jurisdição constitucional (2015, p. 372-393). Segundo o professor, a crítica feita aos

\footnotetext{
${ }^{32}$ No trecho original: "Second-order reasons can push a judge who believes he is right to alleviate his first-best choice and join the group. Sometimes, judges may concede in the name of the symbolic and political power of a unanimous decision, as opposed to the susceptibility of divided ones".

${ }^{33}$ Hübner Mendes salienta que "o colegiado força os participantes da deliberação a encontrar um compromisso principiológico nas situações em que o acordo espontâneo mostra-se inviável. O desacordo sobrevive apenas quando o compromisso principiológico não se faz possível. Um corpo colegial induz ao espírito da acomodação, uma preferência-padrão pelo comprometimento em vez da concorrência ou da dissidência, uma vontade de localizar os pontos de conflito e dissolvê-los" (2014, p. 131). No original: "Collegiality pushes deliberators to find principled compromise where spontaneous agreement proves unviable. Disagreement survives only when principled compromise is not possible. A collegial body induces a spirit of accommodation, a default preference for compromising instead of concurring or dissenting, a willingness to locate points of conflict and dissolve them. It implies a pressure to deflect 'in deference to one's colleagues"”.
} 


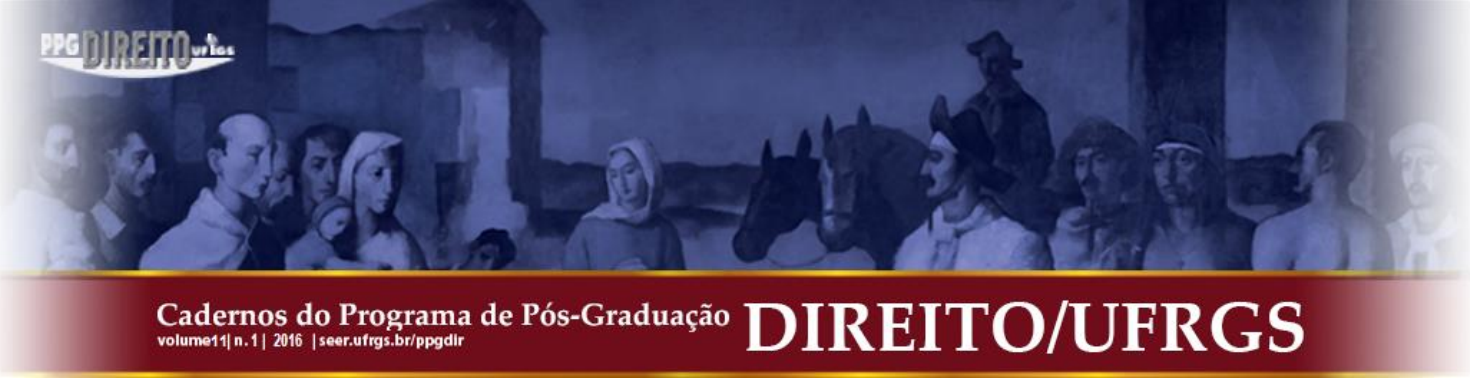

tribunais é relevante para o equacionamento da ideia de colegialidade, ainda que se chegue à conclusão de que um sistema de precedentes judiciais vinculantes é legítimo. Isso porque, em sua inserção no Estado Democrático de Direito, “o processo de deliberação de uma corte deve se ajustar às condições que definem as circunstâncias de adequação da revisão judicial" (BUSTAMANTE, 2015, p. 384, tradução livre), ${ }^{34}$ de modo que, "se um juiz em um colegiado não está convencido da correção da decisão do órgão, as exigências de justeza e de respeito aos interlocutores externos impõem que ele explicite as razões de seu desacordo e apresente uma dissidência" (BUSTAMANTE, 2015, p. 390, tradução livre). ${ }^{35}$

O processo democrático, em sua conformação colaborativa e aberta à deliberação, pressupõe a assunção de uma postura de transparência não só entre os membros do colegiado judicial, mas principalmente entre o colegiado propriamente dito e as esferas externas de debate público e realização do direito e da política. Nessa defesa, não se discute que a adoção do contraditório como influência e não surpresa na formação e aplicação dos precedentes ${ }^{36}$ notadamente pelo uso da técnica das causas-piloto, para uma implementação pro futuro do enunciado $^{37}$ - reclama a percepção de que as dissonâncias nos votos proferidos em um acórdão dificilmente proverão uma única ratio decidendi. É o que também adverte Thomas de Bustamante:

(...) em um julgamento colegiado pode acontecer que os juízes que integram a câmara ou turma de julgamento cheguem a um consenso sobre a solução a ser dada para o caso sub judice mas divirjam acerca das normas gerais que são concretizadas no caso em questão e justificam a solução adotada (...). Nesse sentido, Whittaker recorda o caso Shogun Finance Ltd. vs Hudson, em que o raciocínio de cada um dos juízes que compõem a maioria - uma maioria de três a dois - difere muito significativamente dos demais (...). Em um caso como esse não se pode falar em um precedente da corte acerca das normas (gerais) adscritas que constituem as premissas normativas adotadas por cada um dos juízes da maioria, embora se possa falar, eventualmente, de uma decisão comum constante da norma individual que corresponde rigorosamente aos fatos do caso e às conclusões adotadas. Apenas há um precedente do tribunal em relação às questões que foram objeto de consenso dos seus membros. (...) Isso não impede, porém, que se possa falar em uma ratio decidendi da opinião de um juiz e que a regra inferida dessa ratio seja utilizada

${ }^{34} \mathrm{O}$ excerto no original foi retirado da seguinte passagem: "If the argument for constitutional courts is conditional, as I believe it to be, then the process of deliberation of the court must be adjusted to fit the conditions which define the adequate circumstances for judicial review".

${ }^{35}$ No original: "If a judge in a panel is unconvinced of the rightness of the decision of the court, the exigencies of fairness and respect to the 'external interlocutors' require her to disclose the reasons for this disagreement and deliver a minority opinion (...)".

${ }^{36}$ Sobre a referida abordagem, cf. Nunes (2004, p. 73-85) e Nunes e Theodoro Júnior (2009a, p. 177-206; 2009b, p. 107-141).

${ }^{37}$ Para uma análise do procedimento-modelo alemão e sua interface com o incidente de resolução de demandas repetitivas brasileiro, cf. Nunes e Dilly Patrus (2013, p. 471-483). 


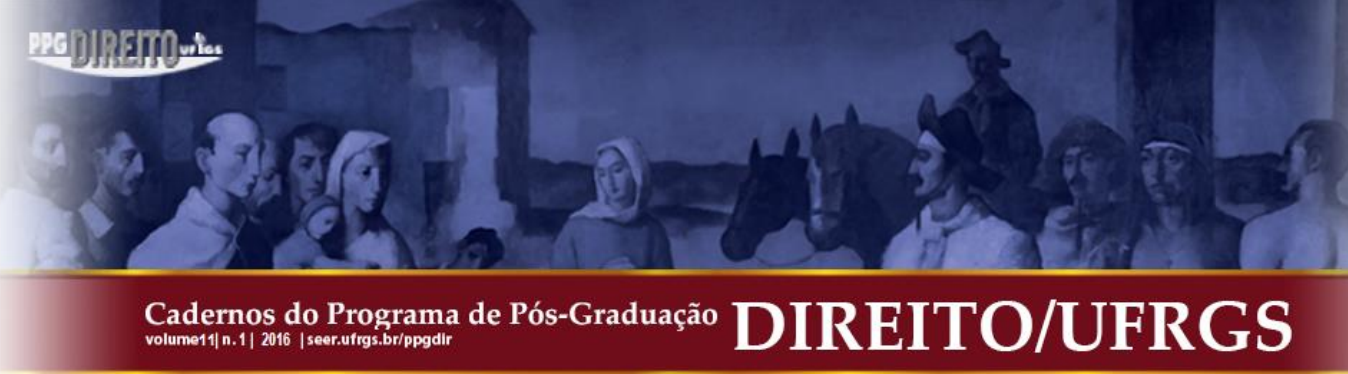

como precedente em um caso futuro. É claro que essa regra está menos revestida de autoridade que outra que tenha sido objeto de consenso de toda a corte, mas isso apesar de limitar - não extingue por completo seu valor como precedente (BUSTAMANTE, 2012, p. 272-273).

Isso não significa, em contrapartida, que o contraditório deva impor uma linearidade ao debate instaurado. Debate obrigatoriamente linear não é debate. A eficácia panprocessual dos argumentos constantes da decisão, inclusive para uma aplicação isolada, mediante um acolhimento por amostragem, não está necessariamente ligada à unanimidade decisória. Não se questiona a fragilidade da autoridade do precedente não unânime, mas a consciência acerca dessa fragilidade não autoriza a fabricação de unanimidades forjadas, irreais, divorciadas da realidade do contraditório na arena público-processual.

\subsection{Deliberação e intensidade de preferências: o valor da divergência}

Em sua tese da democracia como processo decisório, Giovani Sartori explica a natureza das decisões, distinguindo-as em quatro categorias fundamentais (1994, pp. 286-321). São elas: as decisões individuais, tomadas pelo indivíduo isoladamente, sobre si próprio ou o mundo exterior; as decisões grupais, tomadas por um grupo concreto de indivíduos; as decisões coletivas, tomadas pela coletividade, isto é, um organismo não passível de definição, "que não atua e não pode atuar - devido a seu tamanho - da mesma forma que grupos concretos" (SARTORI, 1994, p. 287); e, por fim, as decisões coletivizadas, que se aplicam e são impostas a uma coletividade independentemente de quem as tomou. As decisões políticas, em um sentido bastante amplo, afiguram-se como essencialmente coletivizadas.

Diante da questão atinente a como devemos proceder ao coletivizar as decisões, o autor concebe dois instrumentos analíticos: os custos e os riscos decisórios. Toda decisão não individual impõe custos, e toda decisão coletivizada implica riscos. O custo é de natureza interna ao processo decisório e diz respeito à despesa material e humana relativa ao procedimento de alcance da decisão. Já o risco é de ordem externa, porquanto ligado à possibilidade (sempre presente, em maior ou menor medida) de insucesso da decisão. Ou seja: ao definirmos o caminho a seguir, há sempre o risco de o resultado obtido não corresponder às expectativas iniciais. "Um custo é determinável e, em geral, é determinado (ao menos ex post). Um risco é, ao invés, uma indeterminação ex ante" (SARTORI, 1994, p. 290). 


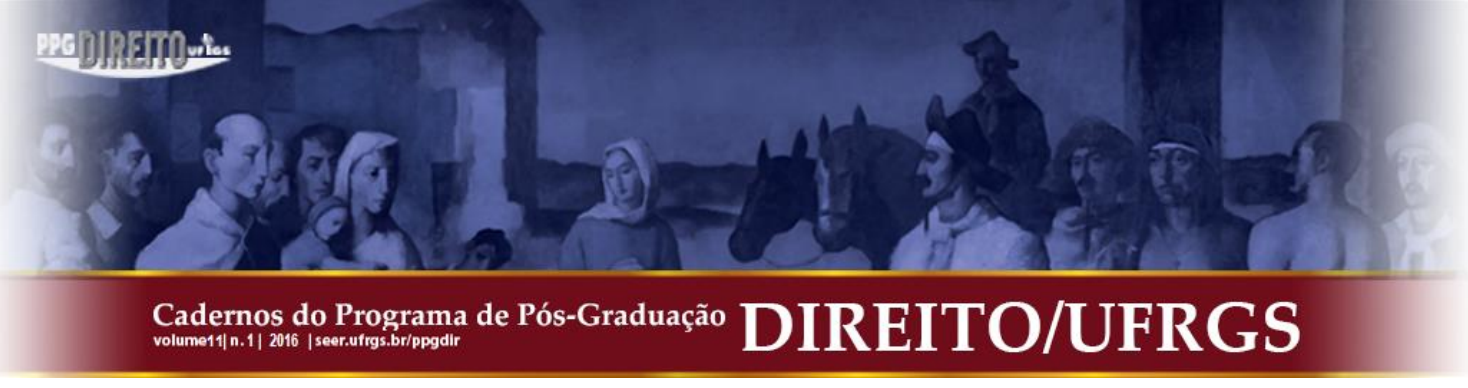

Embora, como já afirmado, as decisões coletivizadas pressuponham sempre uma certa dose de riscos externos, nem sempre tais riscos se consubstanciam em algum prejuízo. No procedimento decisório, porém, o que se busca é a maximização da probabilidade de resultados satisfatórios e a minimização da probabilidade de resultados danosos. De forma geral, "o custo das decisões é uma função do tamanho do órgão decisório" (SARTORI, 1994, p. 291). Isso importa em afirmar que, atribuindo voz e vez a cada participante, quanto maior o número de pessoas que tomam a decisão, mais elevados serão os custos. Por consequência, mostra-se irracional a construção baseada no aumento despropositado do número de pessoas envolvidas no ato de decidir. Usa-se o termo "despropositado", uma vez que pode evidentemente haver um propósito que justifique o alargamento do quantitativo decisório. Tal propósito, porém, deve ser mensurado à luz do prejuízo que causa, uma vez que enseja uma inevitável elevação de custos, levando à burocratização do processo decisório. Para as decisões coletivizadas, entre as respostas possíveis, a mais convincente é a que se volta à proteção dos afetados pelo ato. Em outras palavras, admite-se um aumento dos custos para reduzir os riscos. Nessa conformação, o número de pessoas que toma decisões está em relação inversa com os riscos externos; portanto, "à medida que o órgão decisório cresce, os riscos externos diminuem" (SARTORI, 1994, p. 292).

É certo que, para pensar a democracia constitucional, não se pode levar em consideração apenas a grandeza do quantitativo subjetivo participante do processo de tomada de decisão. Inicialmente, qualquer raciocínio que considere a legitimidade (e, por conseguinte, a legitimação) dos resultados decisórios, procedimentalmente concebidos, depende de uma abordagem que dê conta da emergência de um direito ao mesmo tempo contingente, modificável e coercitivo, que se despiu, na modernidade, do ancoramento metafísico ou religioso. Em vista da insuficiência das respostas liberal e republicana, Habermas defende a edificação de uma legitimidade que se reconstrói na esfera pública a partir de um referencial que concebe a autonomia privada (os direitos fundamentais, garantidos por meio do domínio do direito) e a autonomia pública (a cidadania, que pressupõe os direitos de comunicação e participação no universo público-decisório) como grandezas equiprimordiais e interdependentes (1992, pp. 135-150). ${ }^{38}$ A relação radical entre o Estado de Direito, escorado

\footnotetext{
38 Segundo o filósofo alemão, "no círculo que envolvia o poder entendido instrumentalmente e o direito instrumentalizado, abriu-se uma brecha carente de legitimação (...). Pois as condições de constituição desse complexo evolucionário envolvendo o direito e a política, que tornara possível a passagem para sociedades 


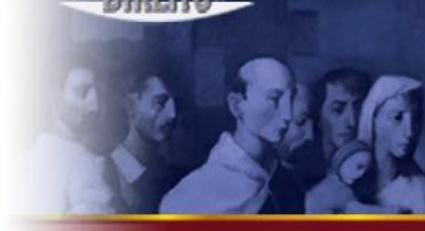

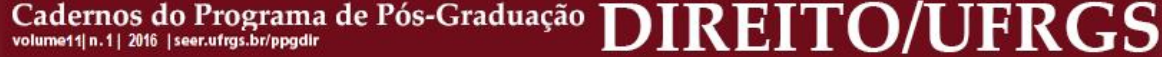

na exigência de juridificação dos direitos fundamentais, do devido processo legislativo e do devido processo constitucional, e a democracia, baseada no espaço de exercício de uma soberania popular constituída por uma comunidade de cidadãos que se reconhecem livres e iguais, é primordial:

\begin{abstract}
A ideia da autonomia jurídica dos cidadãos exige, isso sim, que os destinatários do direito possam ao mesmo tempo ver-se como seus autores. (...) Não há direito algum sem a autonomia privada de pessoas do direito. Portanto, sem os direitos fundamentais que asseguram a autonomia privada dos cidadãos, não haveria tampouco um médium para a institucionalização jurídica das condições sob as quais eles mesmos podem fazer uso da autonomia pública ao desempenharem seu papel de cidadãos do Estado. Dessa maneira, a autonomia privada e a pública pressupõem-se mutuamente, sem que os direitos humanos possam reivindicar um primado sobre a soberania popular, nem essa sobre aquele (HABERMAS, 2002, p. 301).
\end{abstract}

À luz desse referencial, uma soberania popular que se expressa em conexão com as liberdades subjetivas está também entrelaçada com o poder politicamente organizado, possibilitando que a máxima "todo o poder emana do povo", prevista no parágrafo único do artigo $1^{\circ}$ da Constituição de 1988, seja concretizada por meio dos "procedimentos e pressupostos comunicativos de uma formação institucionalmente diferenciada da opinião e da vontade" (HABERMAS, 1997, p. 173). Em anotação sobre o referido parágrafo único, Marcelo Cattoni de Oliveira esclarece que "hoje, o princípio da democracia envolve o reconhecimento de uma noção mais ampla de esfera pública política que não se reduz aos fóruns oficiais do Estado, assim como de uma renovada concepção de sociedade civil (...)", no sentido de um complexo constituído por grupos, associações e organizações "que se diferenciam tanto da esfera governamental, quanto do mercado, e que visam à dramatização e generalização de temas e problemas que dizem publicamente respeito aos diversos âmbitos da sociedade (...)". Daí a conclusão de que "democracia hoje é (...) democracia constitucional” (CATTONI DE OLIVEIRA, 2013, p. 139).

Nesses termos, a abertura do processo decisório às instâncias espontâneas da esfera pública importa sobretudo em medida de legitimação da própria decisão pública. Trata-se de dimensão que, a toda evidência, não pode ser negligenciada. Assim, mostram-se também essenciais os elementos do método de formação do órgão decisório e da regra de tomada de

organizadas em forma de Estado, foram feridas na medida em que o poder político não podia mais legitimar-se por intermédio de um direito legítimo a partir de si mesmo. A razão deveria substituir a fonte sagrada do direito, (...). O conceito de autonomia política, apoiado em uma teoria do discurso, abre uma perspectiva completamente diferente, ao esclarecer por que a produção de um direito legítimo implica a mobilização das liberdades comunicativas dos cidadãos" (1997, p. 185). 


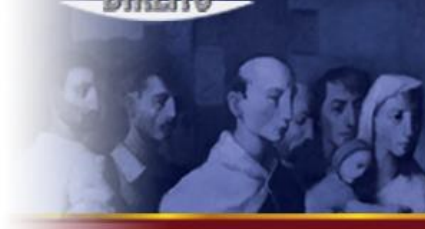

decisões. O primeiro diz respeito à forma de recrutamento ou de designação daqueles que, em maior ou menor número, efetivamente tomarão a decisão; e o segundo refere-se aos princípios e às regras procedimentais para o ato de decidir. Para a operacionalização do traçado de metas e da definição de rumos, "temos de chegar a um equilíbrio entre a conveniência (redução dos custos decisórios) e a segurança (redução dos riscos externos)" (SARTORI, 1994, p. 296), sendo que esse equilíbrio variará a depender do grau de relevância atribuído a cada dimensão. A chave para o equacionamento da formação do órgão decisório está, portanto, no instituto da representação, ${ }^{39}$ cuja amplitude na dinâmica democrática contemporânea pressupõe um entrelaçamento necessário com a ideia de participação (AVRITZER, 2007, pp. 443-464). ${ }^{40}$ Já que no que se refere ao procedimento de tomada de decisões, é indispensável levar em conta três dimensões: o tipo de resultado, o contexto decisório e a intensidade da preferência daquele que decide (SARTORI, 1994, pp. 297-315).

A análise quanto ao tipo de resultado se resume a uma formulação abstrata; a pergunta, por conseguinte, respeita à soma das vantagens e desvantagens decorrentes da tomada de determinada decisão. À medida que se empreende um afastamento do processo decisório como disputa e uma aproximação do paradigma da deliberação construtiva, da negociação e da comparticipação, passa-se de um referencial de soma zero (uma parte ganha exatamente o que a outra perde) para um de soma positiva, em que todos os envolvidos podem ganhar. Paralelamente, o exame quanto ao contexto decisório parte da dicotomia continuidade/descontinuidade. O contexto decisório será descontínuo quando as opções postas em debate forem distintas e estiverem separadas em extremos. Isso ocorre nos plebiscitos e referendos, por exemplo. Já o contexto contínuo é aquele no qual a decisão se desdobra em muitos atos - uma construção em construção -, permitindo um fluxo deliberativo de revisão das opções previamente estabelecidas e de co-formulação de novas alternativas conclusivas. Também aqui a tônica da nova arena público-decisória é inafastável: a busca por contextos

\footnotetext{
${ }^{39}$ Para uma análise do conceito de representação na modernidade ocidental, cf. Pitkin (1967).

${ }^{40}$ Segundo o autor, "as eleições continuam sendo a maneira mais democrática de escolha dos representantes, mas, uma vez eleitos, estes se encontram com a advocacia de temas e a representação da sociedade civil. Aqueles representantes que ignoram essa representação, seja no âmbito nacional, seja no internacional, tendem a se deslegitimar entre os seus próprios eleitores e têm sido muitas vezes incapazes de implementar a sua própria agenda. (...). Nesse sentido, a questão colocada pela política contemporânea deve ser uma redução da preocupação com legitimidade dessas novas formas de representação e um aumento da preocupação sobre de que modo elas devem se sobrepor em um sistema político regido por múltiplas soberanias. O futuro da representação eleitoral parece cada vez mais ligado à sua combinação com as formas de representação que têm sua origem na participação da sociedade civil" (2007, p. 459). Para uma análise da revisitação do conceito de representação e sua relação no tratamento do problema da pobreza política, cf. Dilly Patrus (2014, pp. 195-210).
} 


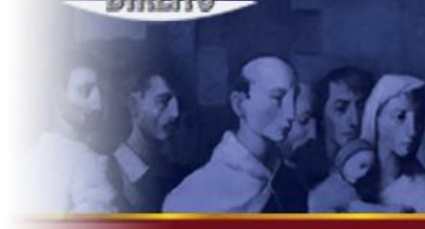

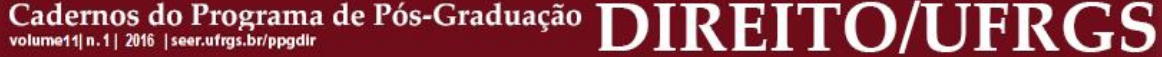

cada vez mais contínuos decorre da centralização de um espaço dialético comparticipativo e deliberativo (HABERMAS, 1992; 1996; NUNES, 2008).

Por último, o fator intensidade exige que se considere que toda questão desperta um grau variado de envolvimento, interesse e convicção principiológica (SARTORI, 1994, p. 300). O desacordo consiste no marco definidor da esfera pública moderna. Apostando nessa constatação, Jeremy Waldron inicia sua obra Law and disagreement com a concisa e eloquente afirmação de que "há muitos de nós, e discordamos sobre justiça" (1999, p. 1, tradução livre) ${ }^{41}$ E avança, afirmando que

nós não apenas discordamos sobre a existência de Deus e o significado da vida; nós discordamos também sobre o que conta como termos justos de cooperação entre pessoas que discordam sobre a existência de Deus e o significado da vida. Nós discordamos sobre o que devemos uns aos outros no tocante a tolerância, paciência, respeito, cooperação e auxílio mútuo. Liberais discordam dos conservadores; socialistas discordam dos economistas de mercado; o partido da liberdade discorda do partido da comunidade, e ambos discordam do partido da igualdade; feministas discordam daqueles que querem que o governo proteja os "valores familiares"; defensores desesperados do Estado de Bem Estar Social discordam dos oponentes triunfantes da tributação; e pragmáticos e utilitaristas discordam daqueles que pensam que a tarefa do direito é vindicar ordem, retribuição e punição (WALDRON, 1999 , p. 1, tradução livre). ${ }^{42}$

Tendo isso em vista, a intensidade da preferência que se expressa no espaço público traduz uma variável de enorme importância, apesar de passar quase sempre desapercebida pela teoria política e pela ciência do direito. É a intensidade que alimenta as afinidades atrativas que aglutinam os grupos concretos, ativando-os na arena deliberativa. Por essa gênese, a maioria é, em regra, não intensa. Uma maioria intensa, embora possível, materializa-se quase sempre em torno de questões pontuais ou de um mesmo núcleo de questões. "Assim, uma maioria intensa equivale a uma maioria ocasional" (SARTORI, 1994, p. 302). Contrariamente, as minorias intensas são grupos reais, não apenas agregados efềmeros. Em última instância, o intenso é ativo, o ativo prevalece sobre o inativo, e só grupos menores e mais homogêneos guardam a envergadura necessária à preservação de uma

\footnotetext{
${ }^{41}$ No original: "There are many of us, and we disagree about justice".

${ }^{42}$ No original: "That is, we not only disagree about the existence of God and the meaning of life; we disagree also about what count as fair terms of co-operation among people who disagree about the existence of God and meaning of life. We disagree about what we owe each other in the way of tolerance, forbearance, respect, cooperation, and mutual aid. Liberals disagree with conservatives; socialists disagree with market economists; the party of freedom disagrees with the party of community and both disagree with the party of equality; feminists disagree with those who want the government to stand up for 'family values'; last-ditch defenders of the welfare state disagree with triumphant opponents of taxation; and pragmatists and utilitarians disagree with those who think the task of law is to vindicate the claims of order, retribution, and desert".
} 


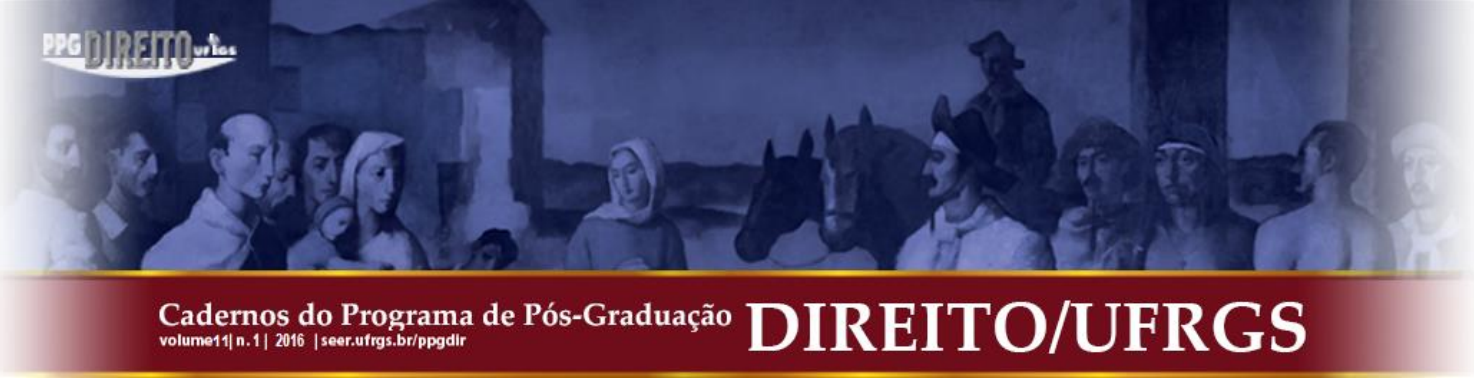

preferência em alto grau de intensidade. A heterogeneidade - o pluralismo, pautado pela divergência - é marca de conjuntos globais, grupos em maior escala, contextos nos quais as preferências formadas mostram-se inevitavelmente menos intensas. É essa a tônica real da sociedade contemporânea: complexa, apressada, globalizada, plural e, ao mesmo tempo (e paradoxalmente), agregadora.

$\mathrm{Na}$ deliberação pública, os graus variáveis de intensidade de preferência devem obrigatoriamente vir à tona. A maioria, apesar de dominante, não pode se escorar em uma falsa carapaça de força, porquanto o jogo democrático exige que, pela transparência, as minorias intensas possam pleitear, reivindicar, debater e convencer com base na força da sua preferência. ${ }^{43}$ Esse dinamismo dialético é absolutamente indispensável, já que é a partir dele que os grupos com menos espaço na arena de poder conseguem estruturar canais eficientes de veiculação de suas demandas e de seus interesses, até mesmo pela reinstalação de discussões aparentemente encerradas, mas baseadas em preferências pouco intensas, como em uma decisão judicial não unânime. ${ }^{44}$

\section{CONCLUSÃO}

Para a construção de um sistema de precedentes alinhado aos preceitos constitucionais, a observância do contraditório material constitui medida impositiva. A mensuração desse contraditório, contudo, não pode levar à efetivação de quaisquer providências estruturais. Não se pode confundir a divergência decisória com a falta de integridade na prolação das decisões. O desentendimento é a base de um regime democrático verdadeiramente consciente da pluralidade social. Por isso mesmo, as decisões, especialmente as delineadoras de precedentes

\footnotetext{
${ }^{43}$ Com base na elaboração teórica do paradigma do Estado Democrático de Direito, Habermas escreve que, em vista da adaptação da esfera pública geral (que é ilimitada) a uma "luta pela interpretação de necessidades", a conversão de temas inicialmente privados - como a violência doméstica contra a mulher e a criança - em assuntos com reconhecimento político depende de um percurso sinuoso. Somente por meio de uma "luta por reconhecimento", engendrada publicamente, é que os interesses questionados e as necessidades vindicadas poderão ser articulados nas instâncias políticas responsáveis, pela via da introdução no debate parlamentar e/ou judicial e da posterior formalização no formato de decisões impositivas (HABERMAS, 1992, p. 367-382). A política na democracia deliberativa é, destarte, um espaço de movimentação do poder comunicativo que pressupõe a abertura às esferas privadas e aos fóruns não institucionalizados, que são informais e espontâneos. Para que tal abertura se preserve, é indispensável que as deliberações públicas das quais são extraídas as orientações positivas sejam colocadas em completa evidência, com transparência e honestidade, sobretudo para que a falta de intensidade dos consensos permita a retroalimentação das discussões (apenas aparentemente) encerradas.

${ }^{44}$ Para uma análise dos consensos obtidos nas decisões unânimes proferidas pela Suprema Corte dos Estados Unidos, cf. Corley, Steigerwalt e Ward (2013).
} 


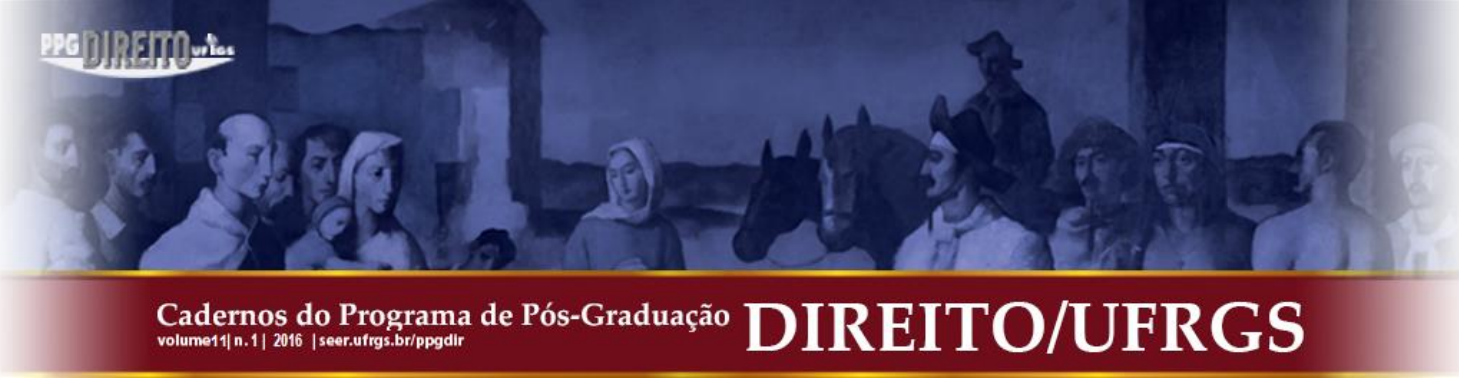

judiciais, devem se manter fieis à sua baixa intensidade, transparentes quanto ao desacordo que não só vigora nos colegiados jurisdicionais, mas em todo o seio social do qual o direito emana e para o qual o direito retorna.

Conforme externado na introdução deste estudo, não se tem a ingênua pretensão de apresentar uma resposta às inúmeras perguntas que precisamos fazer a nós mesmos diante da proposta de um sistema de precedentes vinculantes. Tampouco se pretende estabelecer aqui alguma diretriz para a medida do contraditório, que, à luz do enunciado aprovado no II encontro dos jovens processualistas do IBDP, ocorrido em Salvador, determinará a força vinculante do argumento aplicado como precedente. O que se quer, em verdade, é impugnar o senso de que a praticidade processual (que decorre da percepção da força simbólica dos precedentes formados a partir de decisões unânimes) deva suplantar a exigência democrática de transparência a respeito das divergências que pululam o ato decisório.

Outrossim, não se afirma com isso que a forma como os tribunais decidem no Brasil não merece reparos. O argumento é o de que uma leitura pragmática do princípio da colegialidade não traduz adequadamente o vocabulário da imparcialidade, da dialética principiológica e do contraditório, marcas essenciais de um espaço judicial que se quer aberto à canalização de lutas por direitos. Destarte, é preciso rever a percepção de que a implementação de um sistema de precedentes vinculantes implica a importação de algum método estrangeiro de deliberação colegiada. A própria necessidade de estabilização e preservação da jurisprudência, que constitui elemento indissociável da dinâmica de um regime pautado na observância obrigatória das orientações estabelecidas pelos tribunais, não pode ser pensada a partir da desvalorização das divergências no curso do processo decisório. Em um país que se quer cada vez mais democrático, um aparato processual legítimo e adequado é aquele que confia na esfera pública como sendo um conjunto de indivíduos suficientemente livres e autônomos para assumir a responsabilidade política pela assimilação, avaliação e reconstrução dos precedentes judiciais. Para que isso funcione, todavia, é indispensável que os órgãos jurisdicionais estejam dispostos a servir com transparência e humildade. 


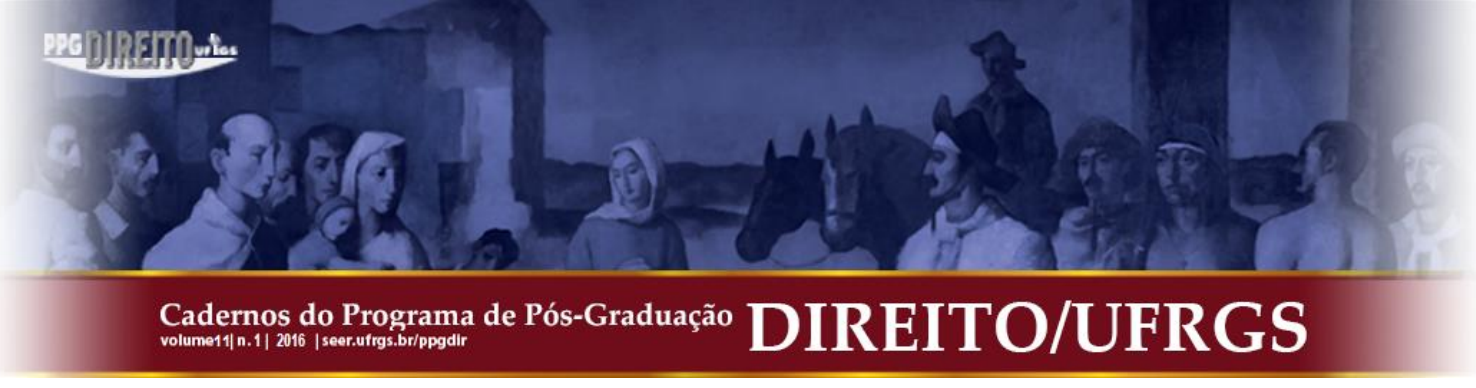

CATTONI DE OLIVEIRA, Marcelo Andrade. Teoria da Constituição. Belo Horizonte: Initia Via, 2012.

Art. $1^{\mathrm{o}}$, parágrafo único. In: CANOTILHO, Joaquim José Gomes; MENDES, Gilmar Ferreira; SARLET, Ingo Wolfgang; STRECK, Lenio Luiz (coords.). Comentários à Constituição do Brasil. São Paulo: Saraiva/Almedina, 2013, p. 137-140.

CORLEY, Pamela C.; STEIGERWALT, Amy; WARD, Artemus. The puzzle of unanimity: consensus on the United States Supreme Court. Stanford, CA: Stanford University Press, 2013.

DANTAS, Bruno. Concretizar o princípio da segurança jurídica: uniformização e estabilidade da jurisprudência como alicerces do CPC projetado. In: FREIRE, Alexandre; DANTAS, Bruno; NUNES, Dierle; DIDIER JR., Fredie; MEDINA, José Miguel Garcia; FUX, Luiz; CAMARGO, Luiz Henrique Volpe; OLIVEIRA, Pedro Miranda de (orgs.). Novas tendências do processo civil: estudos sobre o projeto do novo CPC. Salvador: JusPodium, 2013, p. 125143.

DERZI, Misabel de Abreu Machado. Modificações da jurisprudência no direito tributário: proteção da confiança, boa-fé objetiva e irretroatividade como limitações constitucionais do poder judicial de tributar. São Paulo: Noeses, 2009.

. A praticidade e o papel institucional do Poder Judiciário: a separação de poderes em jogo. In: MANEIRA, Eduardo; TORRES, Heleno Taveira (orgs). Direito tributário e a Constituição: homenagem ao Professor Sacha Calmon Navarro Coelho. São Paulo: Quartier Latin, 2012, p. 599-646.

DERZI, Misabel de Abreu Machado; BUSTAMANTE, Thomas da Rosa de. O efeito vinculante e o princípio da motivação das decisões judiciais: em que sentido pode haver precedentes vinculantes no direito brasileiro? In: FREIRE, Alexandre; DANTAS, Bruno; NUNES, Dierle; DIDIER JR., Fredie; MEDINA, José Miguel Garcia; FUX, Luiz; CAMARGO, Luiz Henrique Volpe; OLIVEIRA, Pedro Miranda de (orgs.). Novas tendências do processo civil: estudos sobre o projeto do novo CPC. Salvador: JusPodium, 2013, p. 333362.

DILLY PATRUS, Rafael. Representação e pobreza política: invisibilidades e inclusão na arena pública do Brasil democrático. In: ALVES, Cândice Lisbôa. Vulnerabilidades $e$ invisibilidades: desafios contemporâneos para a concretização dos direitos humanos. Belo Horizonte: Arraes, 2014, p. 195-210. 


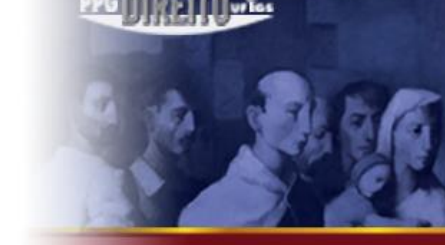

Cadernos do Programa de Pós-Graduação volume11|n.1| 2016 | seer.ufrgs.br/ppgdir

\section{DIREITO/UFRGS}

DWORKIN, Ronald. Taking rights seriously. Cambridge, MA: Harvard University Press, 1978.

. A matter of principle. Cambridge, MA: Harvard University Press, 1985.

. Law's Empire. Cambridge, MA: Belknap, 1986.

. Freedom's Law: The Moral Reading of the American Constitution. Cambridge, MA: Harvard University Press, 1996.

. Justice in Robes. Cambridge, MA: Belknap, 2006.

EDWARDS, Harry T. Collegiality and decision-making on the D. C. Circuit. Virginia Law Review. v. 84, 1998, p. 1.335-1.370.

. The effects of collegiality on judicial decision making. University of Pennsylvania Law Review. v. 151, n. 5, 2003, p. 1.639-1.1689.

ELY, John Hart. Democracy and distrust. Cambridge, MA: Harvard University Press, 1980.

GÜNTHER, Klaus. The sense of appropriateness: application discourses in morality and law. Trad. John Farrell. New York: State University of New York, 1993.

HABERMAS, Jürgen. Faktizität und Geltung: Beiträge zur Diskurstheorie des Rechts und des demokratischen Rechtsstaates. Frankfurt am Main: Suhrkamp Verlag, 1992.

Die Einbeziehung des Anderen: Studien zur politischen Theorie. Frankfurt am Main: Suhrkamp Verlag, 1996.

. Direito e democracia: entre facticidade e validade. Tradução de Flávio Beno Siebeneichler. Rio de Janeiro: Tempo Brasileiro, 1997.

. A inclusão do outro: estudos de teoria política. São Paulo: Loyola, 2002. 
HÜBNER MENDES, Conrado. Constitutional courts and deliberative democracy. Oxford: Oxford University Press, 2014.

MACCORMICK, Neil. Legal reasoning and legal theory. Oxford: Clarendon, 1978.

MANCUSO, Rodolfo de Camargo. Divergência jurisprudencial e súmula vinculante. São Paulo: Revista dos Tribunais, 2001.

MEDINA, José Miguel Garcia; FREIRE, Alexandre; FREIRE, Alonso Reis. Para uma compreensão adequada do sistema de precedentes no projeto de novo Código de Processo Civil brasileiro. In: FREIRE, Alexandre; DANTAS, Bruno; NUNES, Dierle; DIDIER JR., Fredie; MEDINA, José Miguel Garcia; FUX, Luiz; CAMARGO, Luiz Henrique Volpe; OLIVEIRA, Pedro Miranda de (orgs.). Novas tendências do processo civil: estudos sobre o projeto do novo CPC. Salvador: JusPodium, 2013, p. 679-702.

MELISSARIS, Emmanuel. Diachronic universalization and the law. In: BANKOWSKI, Zenon; MACLEAN, James (orgs.). The universal and the particular in legal reasoning. Aldershot: Ashgate, 2006, p. 129-141.

NUNES, Dierle José Coelho. O princípio do contraditório. Revista Síntese de Direito Civil e Processo Civil. v. 5, n. 29, maio-jun. 2004, p. 73-85.

Direito constitucional ao recurso: da teoria geral dos recursos, das reformas processuais e da comparticipação nas decisões. Rio de Janeiro: Lumen Juris, 2006.

- Processo jurisdicional democrático: uma análise crítica das reformas processuais. Curitiba: Juruá Editora, 2008.

. Processualismo constitucional democrático e o dimensionamento de técnicas para a litigiosidade repetitiva: a litigância de interesse público e as tendências "não compreendidas" de padronização decisória. Revista de Processo. v. 199, 2011, p. 41-82.

NUNES, Dierle José Coelho; DILLY PATRUS, Rafael. Uma breve notícia sobre o procedimento-modelo alemão e sobre as tendências brasileiras de padronização decisória: um contributo para o estudo do incidente de resolução de demandas repetitivas brasileiro. In: FREIRE, Alexandre; DANTAS, Bruno; NUNES, Dierle; DIDIER JR., Fredie; MEDINA, José Miguel Garcia; FUX, Luiz; CAMARGO, Luiz Henrique Volpe; OLIVEIRA, Pedro 


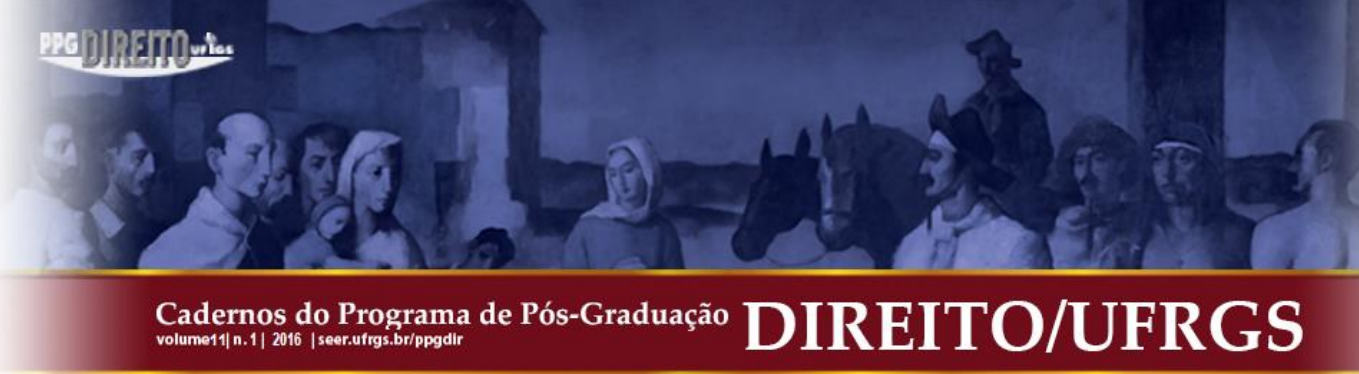

Miranda de (orgs.). Novas tendências do processo civil: estudos sobre o projeto do novo CPC. Salvador: JusPodium, 2013, p. 471-483.

NUNES, Dierle José Coelho; THEODORO JÚNIOR, Humberto. Princípio do contraditório: tendências de mudança de sua aplicação. Revista da Faculdade de Direito do Sul de Minas. v. 28, 2009a, p. 177-206.

. Uma dimensão que urge reconhecer ao contraditório no direito brasileiro: sua aplicação como garantia de influência, de não surpresa e de aproveitamento da atividade processual. Revista de Processo. v. 168, 2009b, p. 107-141.

PEDRON, Flávio Quinaud. As contribuições e os limites da teoria de Klaus Günther: a distinção entre discursos de justificação e discursos de aplicação como fundamento para uma reconstrução da função jurisdicional. Revista da Faculdade de Direito - UFPR. n. 48, Curitiba, 2008, p. 187-201.

PITKIN, Hanna. The concept of representation. Berkeley: University of California Press, 1967.

RAWLS, John. Political liberalism. New York: Columbia University Press, 2005.

RAZ, Joseph. Ethics in the public domain: essays in the morality of law and politics. Oxford: Clarendon, 1994.

SARTORI, Giovanni. A teoria da democracia revisitada: o debate contemporâneo. São Paulo: Editora Ática, 1994.

STRECK, Lenio Luiz; SITO, Santiago Artur Berger. A crítica hermenêutica e a cisão dos discursos em Klaus Günther. Novos Estudos Jurídicos (Online). v. 17, 2012, p. 456-468.

WALDRON, Jeremy. Law and Disagreement. Oxford: Oxford University Press, 1999. 


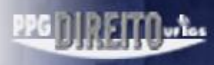

Cadernos do Programa de Pós-Graduação volume11| n.1| 2016 | seer.ufrgs.br/ppgditr

DIREITO/UFRGS 